Investigation concerning a tool: technoeconomical, functional and experimental analysis of Chatelperronian endscrapers from Canaule II (Creysse, Dordogne, France)

Enquête autour d'un outil : approche techno-économique, fonctionnelle et expérimentale des grattoirs châtelperroniens de Canaule II (Creysse, Dordogne, France)

Mickaël Baillet, François Bachellerie et Jean-Guillaume Bordes

\title{
OpenEdition
}

Journals

Édition électronique

URL : http://journals.openedition.org/paleo/3007

DOI : $10.4000 /$ paleo.3007

ISSN : 2101-0420

Éditeur

SAMRA

Édition imprimée

Date de publication : 28 décembre 2014

Pagination : 07-36

ISSN : $1145-3370$

Référence électronique

Mickaël Baillet, François Bachellerie et Jean-Guillaume Bordes, « Investigation concerning a tool: techno-economical, functional and experimental analysis of Chatelperronian endscrapers from Canaule II (Creysse, Dordogne, France) », PALEO [En ligne], 25 | 2014, mis en ligne le 09 juin 2016, consulté le 07 juillet 2020. URL : http://journals.openedition.org/paleo/3007 ; DOI : https://doi.org/ 10.4000/paleo.3007

Ce document a été généré automatiquement le 7 juillet 2020.

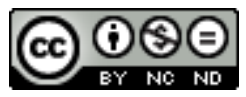

PALEO est mis à disposition selon les termes de la licence Creative Commons Attribution - Pas d'Utilisation Commerciale - Pas de Modification 4.0 International. 


\section{Investigation concerning a tool: techno-economical, functional and experimental analysis of Chatelperronian endscrapers from Canaule II (Creysse, Dordogne, France)}

Enquête autour d'un outil : approche techno-économique, fonctionnelle et expérimentale des grattoirs châtelperroniens de Canaule II (Creysse, Dordogne, France)

Mickaël Baillet, François Bachellerie et Jean-Guillaume Bordes

We thank Jean-Jacques Cleyet-Merle and all the personnel at the Musée National de Préhistoire des Eyzies, who did everything possible to facilitate our work on this collection. A special mention for André Morala who has guided the Canaule II project from the outset. Thanks to Jacques Chapat for this fruitful collaboration and for his generosity. We wish to thank Hughes Plisson and Emilie Claud for enriching discussions, with materials to hand. We are grateful to Jacques Pelegrin and Michel Lenoir for accepting to make the experimental blanks, as well as to Laurent Bernat and Dominique Fournet for logistic help. Finally, we thank the reviewers for improvements to the manuscript, and we assume full responsibility for the final version.

\section{Introduction to the topic}

\section{A palethnological documentary lacuna}

1 Until recently, the Chatelperronian and the other Upper Palaeolithic techno-complexes were defined on the basis of the typological analysis of lithic tools (Breuil 1911; 
Sonneville-Bordes 1960; Bordes 1972). It was only during the 1990s that technoeconomic and micro-wear approaches to Chatelperronian lithic assemblages, as well as the study of faunal remains, industries in animal matter, personal ornaments and colorants, provided a renewed methodological slant for redefining this techno-complex on the basis of richly documented facts and actions (Bodu 1990; Plisson and Schmider 1990; Pelegrin 1995; Granger and Lévêque 1997; Connet 2002; Sonneville-Bordes 2002; Maíllo 2003; D’Errico et al. 2004; Scandiuzzi 2008; Grigoletto et al. 2008; Rios 2008; Bachellerie 2011; Roussel 2011; Soulier 2013; Dayet et al. 2014).

2 At the same time, these digressions towards palethnographical perspectives still lagged behind the more "usual" issues, revolving around the omnipresent debate concerning the Middle to Upper Palaeolithic transition. This is illustrated by the plethora of articles discussing the chrono-cultural position of the Chatelperronian (Zilhão and d'Errico 2000; Bordes 2002; Zilhão et al. 2006; Pelegrin and Soressi 2007; Hublin et al. 2012), or the biological status of the Chatelperronians (Vandermeersch 1984; Hublin et al. 1996; Bar-Yosef and Bordes 2010).

It is clear that this research crossover resulted in similar conclusions to those of our predecessors. On one hand, the Chatelperronian lithic technical systems are structured by a guiding principle consisting of the production of small rectilinear blades destined to be transformed into Chatelperronian points (or knives), or more generally, into "backed blades" (including retouched backed blades and oblique truncations), while the other tools were made on by-products and second rate products (Pelegrin 1995; Connet 2002; Maíllo 2003; Scandiuzzi 2008; Grigoletto et al. 2008; Roussel 2011;

Bachellerie 2011; Rios et al. 2012). On the other hand, the fact that the Chatelperronian blade blank structured both the physical characteristics of the industry and those of the tool kit, resulted in the differentiation of the Chatelperronian from the last Mousterian techno-complexes, and its attribution to the Upper Palaeolithic (Connet 2002; Scandiuzzi 2008; Roussel 2011; Bachellerie 2011). This result has in addition been firmly backed up by the critical revision of the Chatelperronian series from stratified sites, where the Mousterian-type lithic component (i.e., Levallois elements, side scrapers, etc.) turned out to derive from the infiltration of Mousterian levels towards Chatelperronian levels (Rigaud 1996; Bachellerie 2011). In this context, the central position of the Chatelperronian point/knife in Chatelperronian lithic technical systems, and questions related to its function, led to the focalization of research on this emblematic tool, to the detriment of the other lithic objects. Use-wear studies, in particular, either focused exclusively or mostly on Chatelperronian points/knives (Plisson and Schmider 1990), without managing to elucidate its function, in spite of the fact that this was the main concern of most research (Rios 2008; Grigoletto et al. 2008; Rios 2012).

\section{Main issues}

5 The present contribution thus concentrates on a poorly researched Chatelperronian lithic tool up until now: the end scraper. After the Chatelperronian point, the end scraper is the second most common tool in most of the Chatelperronian lithic series; it is even quantitatively superior to the Chatelperronian point in several cases, in particular in Tambourets (Scandiuzzi 2008), Cueva Morin (Maíllo Fernandez 2003), 
Vieux-Coutets (Grigoletto et al. 2008), la Côte (Pelegrin 1995) and Aranbaltza (Rios et al. 2012).

What interests us here is the role of this tool in the technical system at the site of Canaule II. By that, we mean both its status within the general lithic production system, its role (even its value) in activities and the different modalities involved in tool management from production to discard, including maintenance phases.

Based on this question, we formulated the following aims: recording the modalities of end scraper production, spatial distribution, use modes for the activity they were used for (type of activity, movements involved, type of tool maintenance), the stage in the leather processing cycle that this activity represents, the management (maintenance, recycling) of these end scrapers until they were discarded, and lastly, the significance of their possible variability or diversity.

8 The lithic collection from Canaule II is a privileged assemblage for addressing these questions for several reasons. Firstly, the site contains a single Chatelperronian level which does not appear to be contaminated in any way by other industries (cf. infra), studied recently by F. Bachellerie (2011), using a taphonomic and techno-economic approach. Moreover, this assemblage presents marked typo-technological consistency, and generally speaking, well-preserved spatial organization (Bachellerie et al. 2007; Bertran et al. 2010; Bachellerie 2011). Lastly, an earlier use-wear study by H. Plisson and E. Claud confirmed the relatively good conservation of use-wear marks on the lithic material.

We will now present the site and the corpus of end scrapers in more detail.

\section{Material and methods}

\section{The series in its context}

10 The site of Canaule II was discovered in 1962 during prospecting by foot on the western edge of the Canaule Plateau and was excavated in 1968 and 1969 under the direction of Jean Guichard (cf. Bachellerie et al. 2007, for a summary). It is an open-air site, implanted on the middle terrace of the right bank of the Dordogne River. It is situated 60 metres above the river and seven kilometres upstream of Bergerac. The limestone plateau on which this ancient terrace lies contains rich Bergerac flint deposits in the immediate vicinity of the site (Séronie-Vivien M. and M.-R. 1987; Turq 1992; Demars 1994; Fernandes et al. 2013). This flint is excellent for knapping and was intensively used and widely dispersed during the whole Palaeolithic (Geneste 1985; Boëda et al. 1996; Bourguignon et al. 2004).

11 The site was excavated over a surface of $67 \mathrm{~m}^{2}$ and yielded a single, very thin Chatelperronian level, separated from a Mousterian level by a very structured horizon with a thickness of $14 \mathrm{~cm}$ (Bordes 1970). The industry is exclusively represented by lithic material; the sedimentary environment was not conducive to the conservation of fauna. It is mainly made up of concentrations of knapping products, $99 \%$ of which are in flint. The three-dimensional co-ordinates of 4,980 pieces were recorded, while nearly 10,750 chips of less than $2 \mathrm{~cm}$ were collected during sieving (although sieving was carried out for most of the squares, we do not know whether or not it was systematic, nor do we know what mesh size was used). 


\section{diverse magmatic or metamorphic rocks, collected as pebbles. The last publication} concerning Canaule II refers to 141 tools, comprising 39 end scrapers (Bachellerie et al. 2007). However, work carried out since then, incorporating all the pieces with partial retouch (identifiable with the naked eye or with optical instruments), has now brought this total to 209 tools (Bachellerie 2011; Baillet, ongoing PhD thesis). As for the initial figure for the end scrapers, this has been reduced to $n=33$ specimens. Six pieces clearly turned out to be cores on flakes abandoned in the rough out stage, whereas two other pieces are truncations. The fact that these tools only bear technical marks resulting from their manufacture also enabled us to exclude them from the corpus of end scrapers. Alongside that, new end scrapers on blades were identified using keen optical tools. A characteristic end scraper notch was also identified but is not included in the count.

13 The corpus of end scrapers thus comprises 33 tools, or $15.7 \%$ of the retouched tools. Figure 1 illustrates twelve of these pieces; relatively representative of overall end scraper diversity.

\section{Methods}

First of all, we took diverse morphometric characteristics into account for each end scraper, illustrated in figure 2. These measurements were guided by two main questions: are there different categories of end scrapers in the corpus according to the criteria considered above? If so, are these categories typologically well affirmed, or conversely, are they difficult to distinguish from a morpho-technical viewpoint? For this, we used two ratios allowing us to test the hypothesis of the presence of different categories of end scrapers in our corpus:

- the ratio between the length, the width and the thickness of the blank. This ratio can provide information on the techno-economic status of the blank, given that production is mainly geared towards blades with normative measurements and thickness (Bachellerie 2011);

- the ratio between the width and the height of the retouched working edge and the angle of retouch, which is of interest for assessing the degree of blank consumption. By "degree of consumption", we mean the relative measurement (or extrapolation) of the thickness consumed by retouching the working edge (Shott and Weedman 2006). It is only possible to verify this measurement through refits, but it can be reasonably accurately estimated when the blank has only been slightly retouched (fig. 1). 
Figure1 - Examples of end scrapers from Canaule II. Numbers -1-, -4-, -6-, -8-, -10-, -11-, -12- are in Tertiary chalcedony; numbers $-2-,-3-,-5-,-7-,-9$ - are in Maastrichtian Bergerac flint. Some particularly light-weight working edges allow for a total schematic reconstitution (in dotted lines). Drawings by M. Jarry (Inrap), except $n^{\circ}-6-,-7-,-9-$ and $-11-$ by M.B.
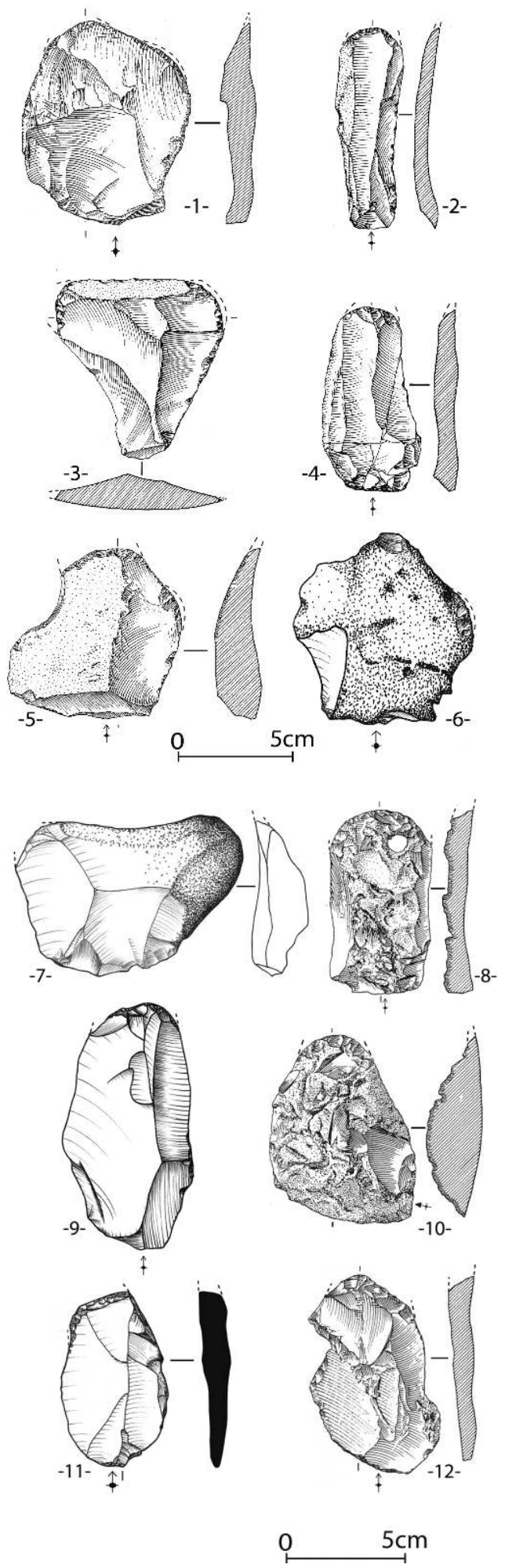
Figure 2 - Main measurements and terminology (after Connet 2002, modified).

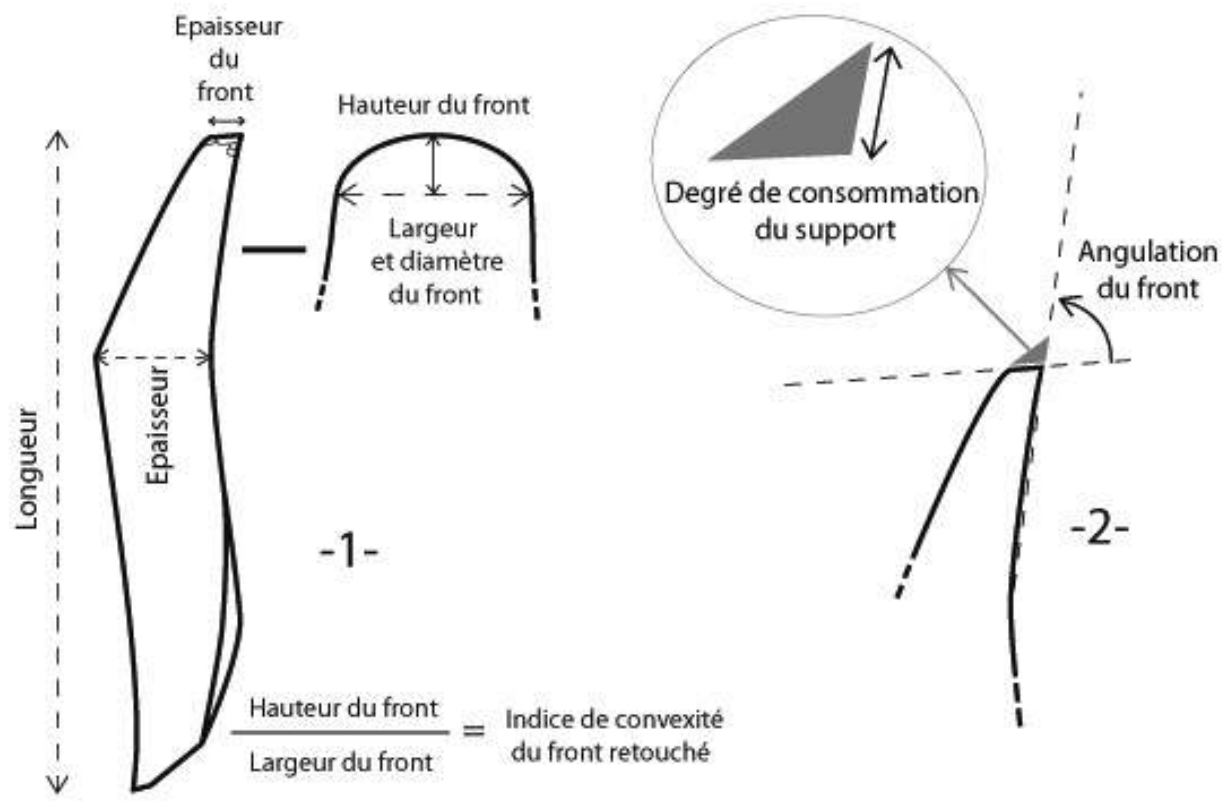

15 Furthermore, before the use-wear study, an experimental reference collection of usewear was created according to the founding principles of the discipline (Semenov 1964; Keeley 1980; Anderson- Gerfaud 1981).

This reference collection corresponds to a protocol adapted both to the archaeological context and our specific research topic (Baillet 2010). As part of this research, Jacques Pelegrin and Michel Lenoir accepted to knap products using the same operative sequences as those identified at the site and the same types of flint as those from Canaule II. In order to be as consistent as possible in our approach, the general morphology of the experimental end scrapers, and in particular, the morphology of the working edge, were as similar as possible to those from the archaeological context.

Using end scrapers and sharp flakes, we worked the main materials used by prehistoric populations: bone, reindeer antler, wood, hard mineral matter (limestone and ochre), earth (sandy and clayey) and hide. As the marks on the archaeological end scrapers are exclusively due to hide processing, as we shall see, we concentrated on this activity in terms of time, the number of tools $(\mathrm{n}=40$ end scrapers and 5 sharp, non-retouched flakes), the number and type of processed skins (one male adult bovine skin, three equid skins, two fox skins, a badger skin, a calf skin, two sheep skins and two marten skins) and texture diversity: fresh, frozen, dried, refreshed hides with added animal fats, chamois hides, dry rigid hides, smoked then refreshed hides, hides with added ochre. We planned these experiments based on the reasoning recommended in particular by H. Plisson (1991). In this way, some of these hides (the cervid skins) were worked by us in the beginning, so that we could grasp the basic processes following an exploratory approach (op. cit.): table 1 (cf. Annex) provides details of these experiments and of the tools used. Then, after the study of the archaeological material, we carried out comparative experiments (op. cit.), designed to be as close as possible to the archaeological context, defined earlier by the functional study of the archaeological tools. These experiments were conducted with Mr. Jacques Chapat, a traditional leather 
tanner working in Puy-en-Velay (Haute-Loire), as part of a three-week collaboration. The aims of this choice were multiple.

First of all, this gave us the possibility to work with other types of skin (particularly in terms of thickness and surface) than the cervid skins used up until then. Secondly, the participation of a tanner craftsman, who has been working manually for over thirty years, using metal knives and ancestral savoir-faire, provided an exceptional opportunity to assess the efficiency of replicas of prehistoric end scrapers in different hide working operations. He is in the best position to intuitively and immediately use the stone tool in the best possible way in technical terms, regardless of the aim and the type of hide. In any given situation, he is the only person who can provide pertinent judgments as to 1) the range of possible motions; 2) the degree of efficiency of a tool (efficiency for the task and gauging the necessity to resharpen the tool. Thirdly, we were sure to be able to use the tools for long periods of time. Table 1 (cf. Annex) provides details of the experiments conducted by Jacques Chapat (or, as the case may be, supervised by him), as well as of the tools used.

The main variables tested during the different experiments are: movement, duration of use, the state of the worked material (linked in particular to humidity content and ambient hygrometry), the method of stretching applied to the skin, and the presence/ absence of a frame. As for the prehension of the end scrapers, some of them were handheld, whereas others were hafted into different wooden handles, with or without a protective leather sheath (cf. table 1 Annex). However, we did not explore the hafting issue further, given that the corpus of specialized literature provides ample references on this topic (e.g., Rigaud 1977; Brink 1978; Hayden 1979; Rots 2002; Beyries and Rots 2008). When end scrapers were rejuvenated, we retouched them with a small, smooth, oblong pebble, using direct handheld percussion. The hafted pieces were systematically removed from the handle for resharpening.

As for natural alterations, we only tested human trampling. Consequently, we used numerous bibliographic references on post-depositional modifications, in order to learn to differentiate them from use-wear, to be conscious of the potential biases they can generate during functional analysis and lastly, to assess their probable origins (e.g., Rottländer 1975; Mansur 1986; Plisson and Mauger 1988; Caspar et al. 2003; Lenoble 2005; Vallin et al. 2013).

We looked for and then examined the use-wear marks on all the surfaces of each piece. The stereomicroscope (magnifications of 5 to $50 \mathrm{x}$ ) was used to describe the macrotraces, and the metallographic microscope (magnifications of 100 to $500 \mathrm{x}$ ) was used to observe any associated micro-traces.

\section{Results}

\section{Techno-economic analysis of the end scrapers}

\section{Nature and morphology of the blanks}

Note that the corpus is made up of 33 pieces. The end scrapers from Canaule II are mainly made on flakes $(n=19)$, but also on laminar flakes or blades $(n=14)$. We do not know what type of blank the resharpening notch is on. 


\section{End scrapers on flakes}

The dimensions of these tools clearly indicate that they were selected from the largest available blanks (length: between 60 and $90 \mathrm{~mm}$; width: between 40 and $100 \mathrm{~mm}$; thickness: between 15 and $30 \mathrm{~mm}$ ), although the biggest flakes were not systematically chosen (fig. 3). More than a third ( $\mathrm{n}=7)$ are primary or sub-primary flakes from blocks. The refits show that most of the flake blanks are from core shaping phases or the maintenance of laminar production. No blocks provide evidence of a specific schema of blank production for end scrapers. The refitting of two end scrapers on two blocks used for non-differentiated flake production backs up this observation. Moreover, one of the blocks bears the same use-wear marks as some of the end scrapers issued from technically evolved laminar debitage.

Tableau 1 - Dimension(en $\mathrm{mm}$ ) des pointes de type Isturitz analysées.

At this stage of the study, it is essential to consider a methodological issue relating to the characterization of flake debitage. At Canaule II, two refitted blocks, to which we must add other non-refitted blocks, have only produced flakes through the debitage of large blanks on a wide surface, which could be interpreted as blanks intended for end scraper fabrication, according to a rigid analysis of the debitage schemas. But if we take a closer look, and incorporate all the knapping actions observed in this industry, it appears that these blocks provide evidence of inexperience and a clear lack of savoirfaire.

After a failed attempt at laminar production, one of these blocks was then reoriented towards the opportunistic production of non-differentiated flakes (Bachellerie 2011).

Other cores, such as those excluded from initial end scraper counts (cf. supra), were abandoned at an awkward shaping stage, similar to that used for the productive blade cores from the series. We observe numerous abandoned attempts at crested debitage with one prepared side on these blocks, or of truncations intended to create a striking platform that did not materialize due to ill-adapted volumetric configuration. These deviant blocks clearly appear to be the work of non-confirmed knappers, who seem to have played a non-negligible role in the composition of the assemblage excavated at Canaule II. As a consequence, we must bear in mind that these "apprentice knappers" must at least have participated in the fabrication of certain tools as well as in the sphere of certain activities that these tools were used for (ad hoc or deferred in time and space).

These observations are applicable to the technocomplex as a whole since there is convergence between certain tool shapes during the Chatelperronian - such as those classically defined by typology - and different stages of the abandonment of flake cores (Pelegrin 1995; Scandiuzzi 2008; Roussel 2011; Bachellerie 2011):

- during the course of blade production, as the smallest blades can be mixed up with different categories of burins (for example at la Côte: fig. 94, $\mathrm{n}^{\circ} 6$ in Pelegrin, 1995);

- during the course of the preparation of a one-sided crest prepared towards the upper surface: these pieces represent a rather coarse imitation of some heavy end scrapers. Nonetheless, this category can be distinguished from end scraper-tools by coarser, irregular and semi-abrupt retouch, as well as less-pronounced convexity. 


\section{End scrapers on blades or laminar flakes}

Fourteen end scrapers are on blanks with a greater length than width, with parallel edges. Eight of them are on laminar flakes and six on blades. In sum, it would be more accurate to say that these fourteen blanks are intentionally longer, but selected among the widest and/or thickest laminar elements, or even from accidents, like plunging blades, for example. In the same way as the end scrapers on flakes, the elongated blanks were selected from the largest available formats (length: between 65 and 120 $\mathrm{mm}$; width: between 30 and $60 \mathrm{~mm}$; thickness: between 10 and $20 \mathrm{~mm}$ ) (fig. 3). Given their morphology, and that of the previous removals on their upper surface, these different blanks seem to have been chosen from shaping or maintenance elements issued from laminar production.

Figure 3 - Comparison between the blanks used for end scrapers and the unmodified blanks (top: flakes; bottom: elongated flakes).
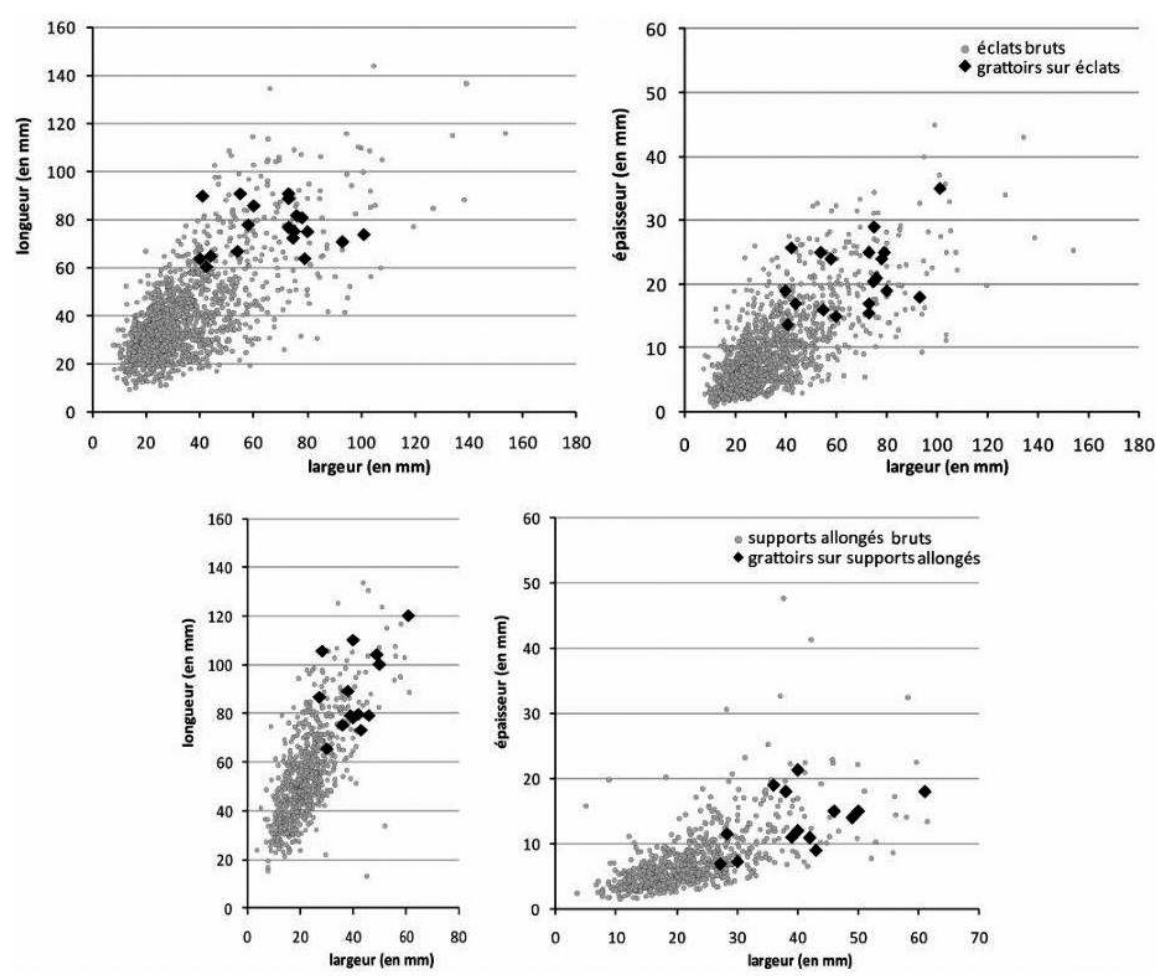

\section{Raw materials}

The majority of the end scrapers observed at Canaule II are in local raw materials. Twenty-three of them are in Bergeracois flint, available in the vicinity of the site. Refits or associations show that these 23 pieces were produced and made on site. A single piece is in black Senonian flint, available several tens of metres from the site, in the Dordogne alluviums, and brought to the site for knapping. There are also nine end scrapers in Tertiary chalcedony, present about ten kilometres south of the site, on the left bank of the Dordogne River (Demars 1994; A. Morala, oral com.). This material seems to have been imported to the site as large flakes, as no evidence of knapping this rock is discernable at the site. On the other hand, it is impossible to evaluate whether the end scrapers were made on site or further upstream. It is difficult to distinguish the 
small Tertiary chalcedony flakes from certain types of translucent Bergeracois flint among the thousands of small flakes collected at the site. Nonetheless, the presence of ten non-retouched flakes in Tertiary chalcedony, some of which are similar in size to the end scraper blanks, tends to imply that the tools were retouched in situ, and brought to the site as non-retouched blanks. This hypothesis is backed up by the fact that two end scrapers in chalcedony, on large cortical flakes of similar thickness (1.5 $\mathrm{cm})$, refit together. As well as that, five end scrapers in chalcedony were found together, clustered over several square metres, relatively far away from the debitage heaps. It thus seems as though these pieces were brought to the site together.

31 Although it is not possible to identify the production schema for the end scraper blanks in Tertiary chalcedony, we can however affirm that their morpho-technical characteristics correspond to the variability observed for those in Bergeracois flint. It thus seems that they do not come from a specific debitage schema.

Given these elements, no differentiated raw material treatment can be identified for the selection of blanks for end scrapers.

In conclusion, the end scraper blanks were chosen among the largest debitage products, regardless of the presence of cortex, of their regularity, and of their laminar proportions. The end scraper blanks in non-local raw materials are of the same type as those selected from on-site debitage waste in local raw materials. At the most, we can observe that the end scrapers are made on blanks with a broad but circumscribed range of dimensions: between 60 and $155 \mathrm{~mm}$ long, 40 and $100 \mathrm{~mm}$ wide, with a thickness of 10 to $30 \mathrm{~mm}$.

Up until now, we appear to have a single population of end scrapers, characterized by wide formal blank variability, and similar large dimensions. In addition, these blanks do not provide evidence of any particular technical investment, as they are mostly selected from blade production by-products.

We will now assess whether this unity remains valid in the light of the observation of the retouched working edges.

\section{Morphology of the retouched edge}

Three out of the 33 analyzed end scrapers present double working edges. Our discussion thus focuses on the observation of 36 retouched edges.

It is important to point out first of all that the retouched ends are differentially located on the longest axis of the blank. We can easily distinguish two types of cases. The first consists in an axial position of the retouched edge on the most protruding end in relation to the centre of the blank. The second consists in an offset position of the retouched edge in relation to the longitudinal axis of the piece, i.e., either in the corner of the most protruding zone, or else on the lateral edges of the piece, on a protruding zone. There are a total of 25 axial working edges and 11 offset working edges. Both of the double end scrapers have an axial and an offset working edge.

In addition, the comparison of the different data (i.e., the width and the height of the working edge, as well as the retouch angle) indicates that there are, as previously described (Bachellerie et al. 2007, p. 266), end scrapers with thin, narrow and rather acute working edges, and others with wider, thicker and semi-abrupt working edges (fig. 4). 
transition from one to the other appears however to follow a continuum, in terms of the dimensions of the working edges, rather than representing several distinctive metric sub-types. Moreover, no particular link seems to exist between the angle of the retouched edges, their convexity and blank morphology (fig. 5).

Furthermore, we note the presence of a notch on the front of five end scrapers (fig. 6). This is deliberately and systematically made away from the working edge, and is cut by retouch in four cases out of five. In two cases, the notch accentuates the curve of the end scraper, and in three cases out of five it clearly allowed for the individualization of two narrow fronts on either side.

41 It is clear that, regardless of the selected blank, the working edge of the end scrapers from Canaule II can be narrow or wide, thin or thick, convex or not, acute or abrupt, with no noticeable correlation between these characteristics. This population of tools thus seems to be characterized by variability on all fronts, from the general shape of the blanks to the morphological details of the fronts and the measurements. We will now see if these proposals can be elucidated by the functional study.

Figure 4 - Relationship between the width and thickness of the working edge, according to the angle of the working edge and the type of blank.

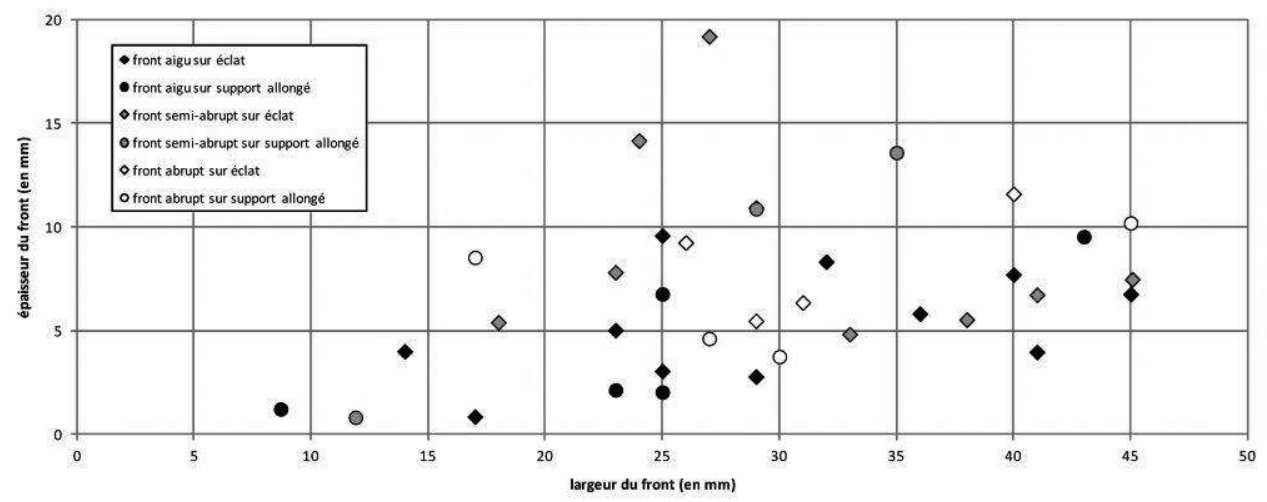

Figure 5 - Convexity index of the fronts, according to the angle of the working edge.

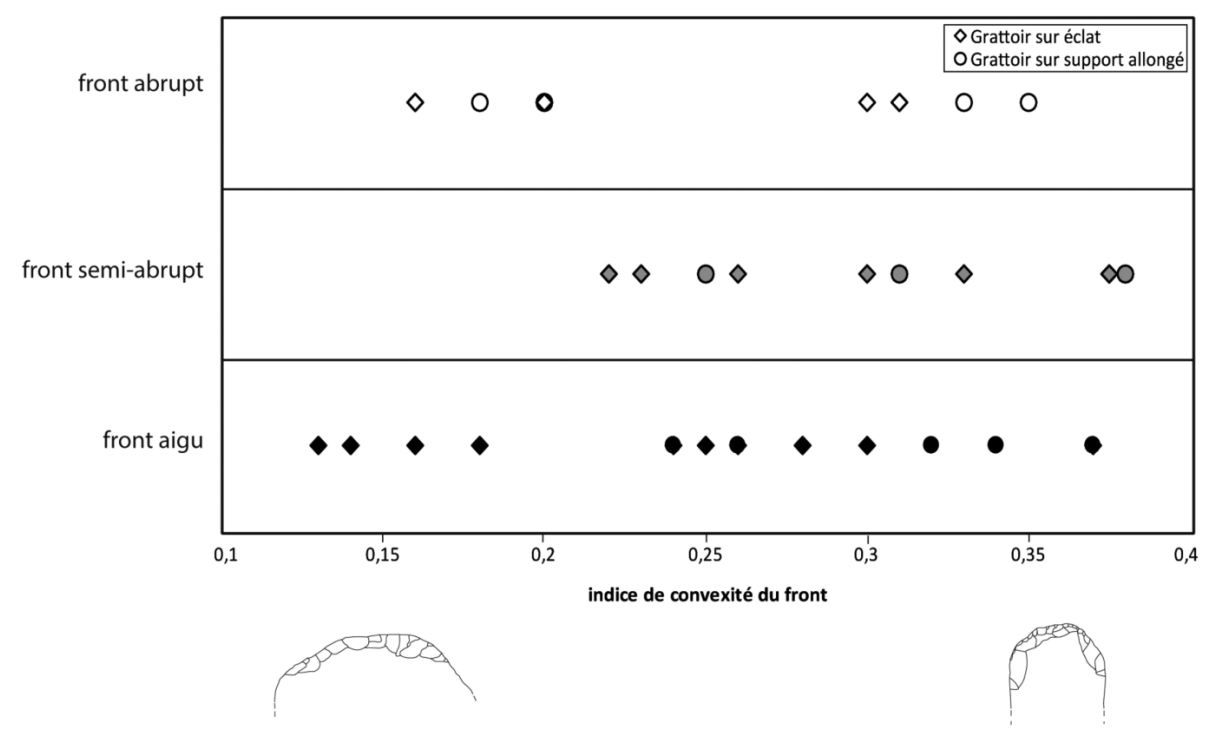


Figure 6 - 1 and 2: Detail of two end scrapers bearing notches (drawing from M. Jarry, Inrap). 3 : lateral side of the working edge, bearing traces of scraping dry skin.

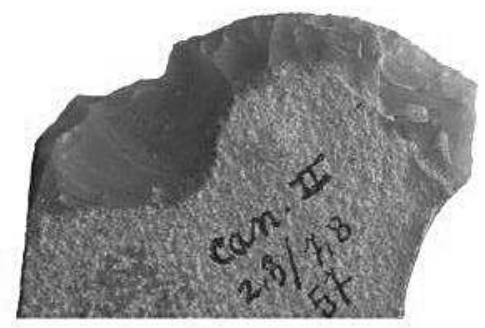

$-1-$

$1 \mathrm{~cm}$
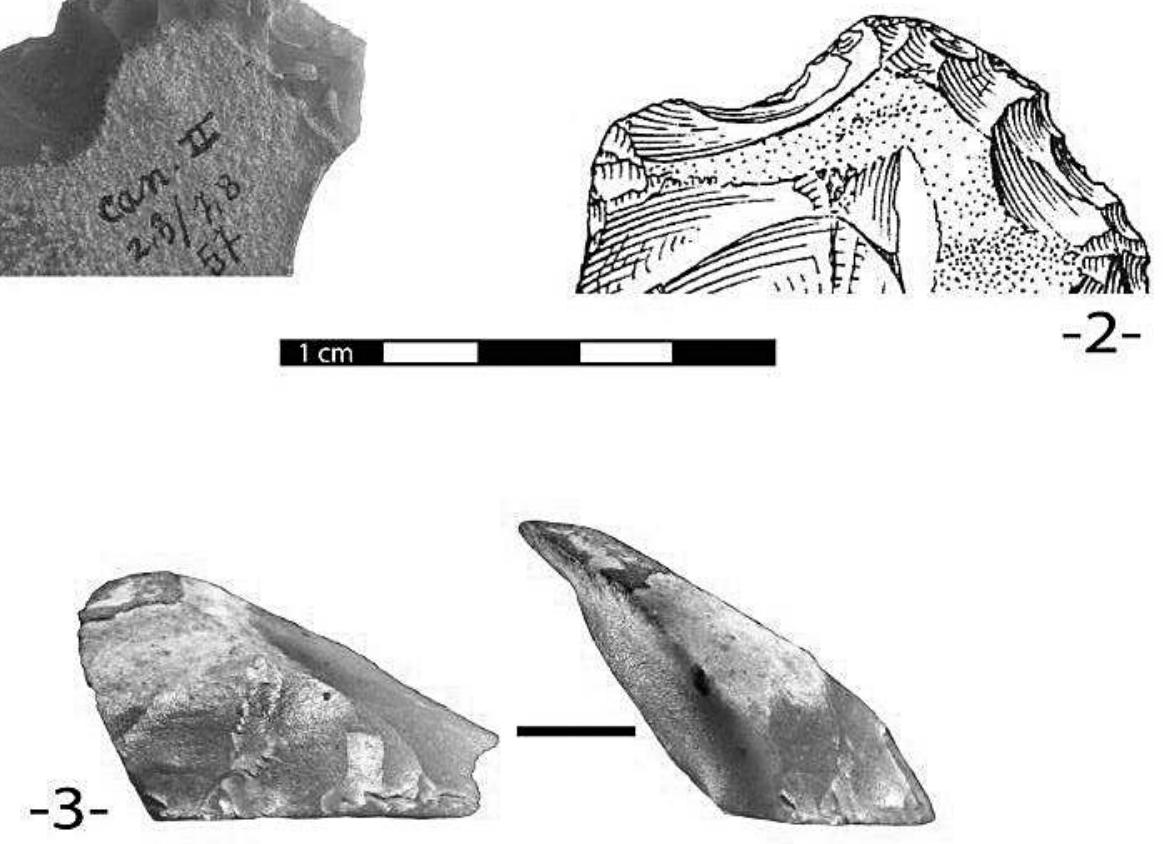

$1 \mathrm{~cm}$

\section{Use-wear analysis}

\section{State of the end scraper surfaces}

The very good macroscopic state of conservation of the pieces was only partially confirmed at a microscopic scale. However, this observation must be qualified as we know that some of the non-retouched flakes in the series revealed characteristic butchery use-wear (H. Plisson and E. Claud, in oralis), and that these traces are among the most fragile in relation to post-depositional alterations (Plisson 1985). We can thus expect that at least part of the series is perfectly apt for functional analysis.

The cutting edges and the ridges of the end scrapers are still sharp and microsplintering of the edges is rare. A more or less marked "soil polish" effect (cf. Plisson and Mauger 1988), slightly affected the higher zones of the flint microtopography of some pieces, whereas the naturally hollow zones remain intact. A single end scraper is affected in places, on the dorsal side, by a zone of natural abrasion polish (sensu Mansur 1986), of non-determined origin. This indicates that very localized and random mechanical phenomena occurred, in the same way as the generalized effects described above. This natural abrasion can destroy even the most enduring micro polish resulting from use, (Plisson 1985), but can nonetheless be easily distinguished from use polish, in particular, due to the inconsistency of its distribution on the piece. As for the white patina, it represents a slight and rather insignificant chemical alteration, as it only hindered the analysis of two pieces.

Low and high magnification analysis was thus possible on all the pieces in the corpus. 


\section{Functional results}

Twelve end scrapers present use-wear on their working edges, including two double end scrapers for which both active zones were used (fig. 1, $\mathrm{n}^{\circ}-1-$ and -3-). The rejuvenating notch only bears use-wear on part of the cutting edge. In total, there are thus fifteen active zones. This "population" (from a micro-wear stance) includes pieces in "Bergeracois" flint $(n=7)$, and in Tertiary chalcedony $(n=5)$. As for the angles of the working edges, seven of them are acute, seven are semi-abrupt, and just one is abrupt (fig. $1, \mathrm{n}^{\circ} 11$ ).

The remaining twenty-one end scrapers did not present traces of use-wear, which is significant as it is important to rule out any doubts as to taphonomic bias (cf. supra). These pieces are in Tertiary chalcedony $(\mathrm{n}=4)$, as well as in "Bergeracois" flint $(\mathrm{n}=16)$ or black Senonian flint $(\mathrm{n}=1)$.

The use-wear traces are exclusively located on the retouched working edge of the end scrapers; we observed no use-wear on the rare retouched lateral edges $(n=3)$, nor on the non-retouched edges or in the large notches on some of the end scraper edges $(n=5)$, even though all these zones were potentially useable. More specifically, the use-wear traces are spread out in a decrescendo way from the centre of the end scraper fronts towards the edges. On one piece, the traces are present at the top of the retouch on the front, that is, $1 \mathrm{~cm}$ above the working edge and not on the edge itself.

The fifteen fronts with use-wear traces exclusively bear marks related to dry hide working. The only experimental operations resulting in similar use-wear to that of the archaeological pieces (fig. 8. -2c-) were hide thinning activities (i.e., exposing the dermis). These will be presented in detail below. The quality of micropolish conservation allowed for a good resolution level in tribological terms: as they indicate that certain end scraper fronts were in contact with very slightly fatty dry hide zones (fig. 7. -1-), whereas others denote an atmosphere with no humidity whatsoever (fig. 7. -2-). In addition, the several striations laid out perpendicularly to the edge and the general orientation of the polish systematically point to a scraping action, while the consistency of the use and the parallel organization of the striations portray a regular movement. Use is restricted to the edge of the working edge, and is systematically delimited by the beginning of retouch on the dorsal side. From this zone onwards, the striations definitively fade out. Dry hide working, whether the hide is stretched or not, with a clearance angle of $90^{\circ}$, would have induced use towards the upper side of the tool, as shown experimentally (cf. infra; table 1, Annex). Conversely, we observed experimentally that this work carried out with a very closed clearance angle tends to generate use-wear towards the underside of the tool (table 1, cf. Annex). Consequently, we can deduce a minima that the fifteen archaeological working edges in question were maintained in an intermediary position around $60^{\circ}$ ?), i.e., neither at $90^{\circ}$, nor in a very low-angled position (fig. 7 -2a and 2b-). In the same way; we can conclude that the skin was stretched (either with a frame, or with a stretching system; cf. fig. 7 -2a-). All this demonstrates that the working edges were used for thinning hide. A single end scraper (in chalcedony, fig. $1 \mathrm{n}^{\circ}$-11-) differs from the others as the use-wear on the front is only represented by an isolated spot, located $5 \mathrm{~mm}$ above the working edge - at the top of the retouch. This spot corresponds to a zone "saved" by the last resharpening of the tool. Therefore, for this piece, the user's motion would have involved a clearance angle of about $90^{\circ}$. This more open angle is logical if we consider that the abrupt nature of 
the working edged resulted in the loss of sharpness, and thus compromised the efficiency of the initial gesture (using an intermediary position of about $60^{\circ}$ if we consider that it was used in the same way as its counterparts). The user would have been forced to adapt the position of the front in relation to the hide in order to continue to thin it effectively. In this way, he would have turned the tool over in his hand, and worked by pulling it towards him at an angle of $90^{\circ}$, using twice as much force to compensate for the loss of sharpness of the working edge. This logical technical adaptation has already been brought to light in other contexts (Semenov 1964, p. 88).

As for the prehension of these tools, we did not observe any traces of hafting. Thus, in order to discuss this issue, it is necessary to present the meagre relevant information from the technological study of these pieces. It is important to recall the absence of standardization in the gripping area (opposite the active zone), the preferential selection of the largest available blanks (cf. supra), and the irregular - cortical - and thick aspect of most of them. All these elements point to bare-handed prehension. As for the rest, our earlier observation regarding the regularity of the use of the active part, which is an argument generally associated with evidence of hafting, is not incompatible with the notion of handheld use. We verified this experimentally by means of specific and repetitive operations.

Use-wear intensity is relatively weak, but nonetheless perfectly characteristic (fig. $7 \mathrm{n}^{\circ}$ -2- and -3-). For one specimen, with very slight micro-blunting of the working edge, accompanied by polish with a mild and grainy coalescence forming occasional small craters, this use is diagnostic of the same material as that worked by its counterparts, with however, very different development. For another piece (fig. $7 \mathrm{n}^{\circ}-1-$ ), on the other hand, the use-wear is a little more developed than for most of the other pieces. As these differences in intensity of the same type of polish can be due to different parameters, such as the duration of the use of the tool, the motion (the angle but also the energy deployed; the type of contact) or the stretching system applied to the skin, we will consider their interpretation below by way of specific experiments.

51 These latter observations must also be related to another of our observations: tool resharpening. On nearly all of the twelve end scrapers, the use-wear consists of a series of discontinuous or completely isolated zones of several millimetres, intersected by posterior retouch (of archaeological age). The latter bears no traces of use, indicating that these end scrapers were not used after the last resharpening (fig. 7. -2-). As hide working does not involve any possibility of auto-sharpening of end scraper fronts (e.g. Collin and Jard $\mathrm{n}$ 1993), this reflects a voluntary resharpening process. One of these is a resharpening notch, bearing continuous traces on the part that corresponds to the centre of the front, whereas the area corresponding to the lateral edge of the front does not bear any. This proves that this is a lateral resharpening notch and is undoubtedly related to the notch scar visible on five end scrapers (fig. 6. -3). On the other hand, for two other specimens with continuous use-wear, we can deduce that one was used in a relatively intensive way, whereas the other displays slight use. These two pieces bear an acute-angled front, and in both cases, the edge is sufficiently sharp to consider that they are still operational. These are the only end scrapers for which we have no elements enabling us to assess whether they were resharpened or not. Nevertheless, all in all, the information from the fifteen fronts in question reveals four strong tendencies in terms of techniques. The tools were only slightly used (i.e., either without 
applying much force or for a very short duration of time), for any given sequence of actions and with a high degree of precision (or regularity). Moreover, it seems that they were resharpened as soon as the slightest sign of dulling appeared. In this way, the prehistoric groups wished to maintain the working edges constantly sharp, through low-angled resharpening in order to conserve an acute angle. These four tendencies are correlated to each other if we consider that these end scrapers were used for hide thinning, an activity requiring a sharp working edge and precise movement. We will reconsider this point below as part of a discussion relating to the correlation between the exact type of activity carried out and the characteristics of the tools. This discussion will also provide the opportunity to explore the question of use-wear intensity in depth, in order to evaluate other related parameters, apart from the precision of the gesture.

Figure 7 - End scraper samples from Canaule II bearing use-wear on their working edges (drawing from M. Jarry and M.B). -1-: Well developed use-wear resulting from scraping dry hide (but still bearing some fat); -2a-: use-wear resulting from the light scraping of completely dry hide; $-2 b-$ : evidence of resharpening; -3-: double end scraper in Tertiary flint, bearing use-wear on both working edges, resulting from the light scraping of completely dry hide.

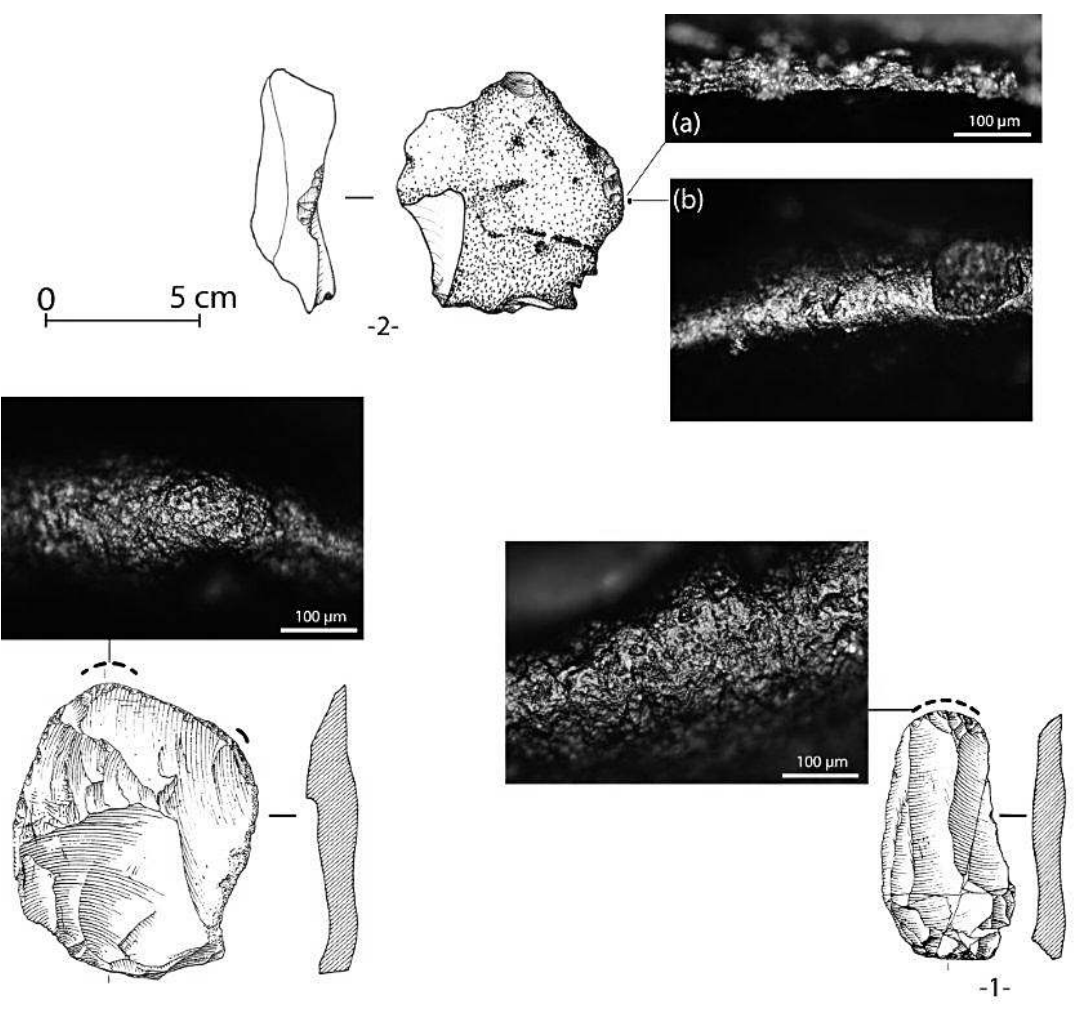


Figure 8 - Comparative experimental sessions scraping completely dry hide (bison) with a traditional tanner. -1a-: the skin is placed on a frame and the craftsman thins down the epidermis on the pelt side; -1b-: schema of removing the epidermis with an end scraper. -2a-: uncovering the dermis (white) by thinning the hypodermis (brown); the skin is placed on a convex wooden frame; the craftsman sits on the stand and pulls the tool towards him.-2b-: schema of tool functioning, thinning down the hypodermis and the dermis. -2c-: microphotograph of use-wear on the experimental tool in -2a-, result after scraping for 10 minutes.
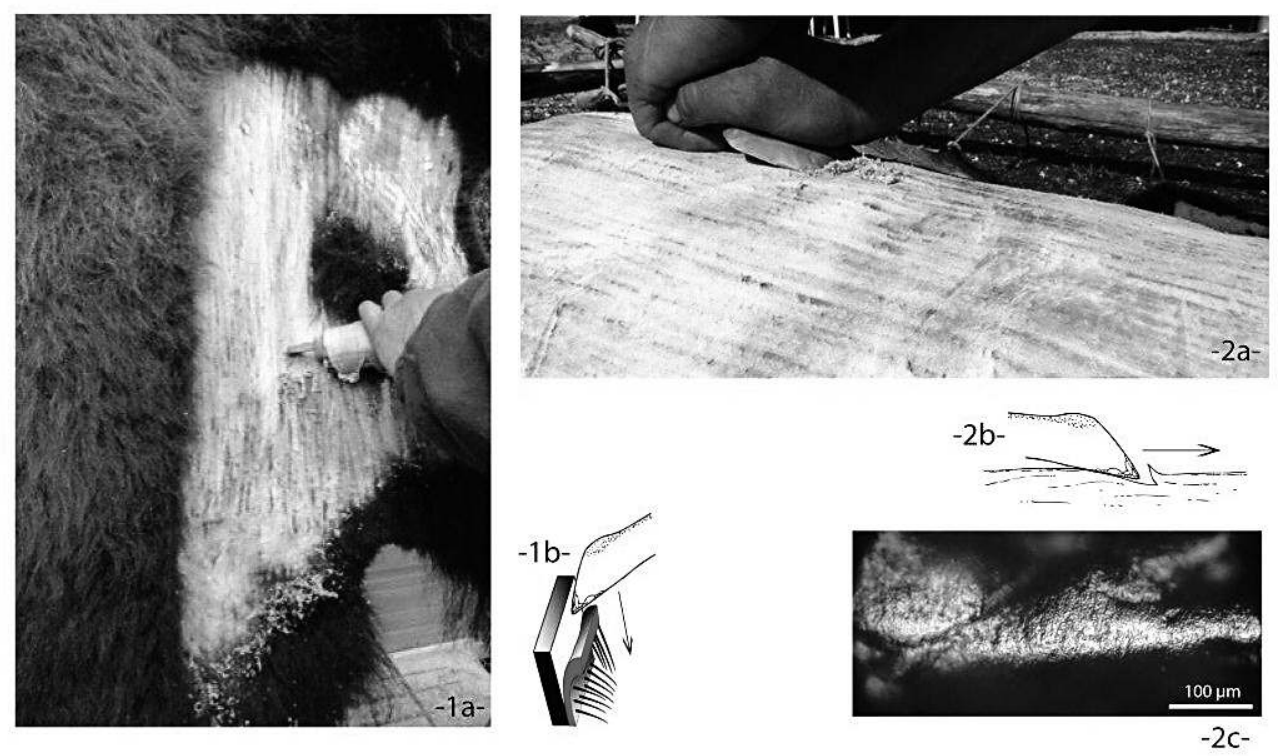

To summarize, these end scrapers were all used to thin hide, were handheld and were used for the same movements. The singularity of one specimen could correspond to an adaptation of the user's gesture during the last phases of the lifecycle of the tool; it would thus be an exception to the global hypothesis advanced here: namely that the end scrapers from Canaule II make up a single family of tools, from a functional perspective.

In our opinion, this observation is significant in relation to the previous result which designates the absence of sub categories, i.e., the absence of shapes, in what is presumed to be a large typological family (cf. supra). But, at the same time, this convergence of information is paradoxical: how can we explain the variability in the working edges of the end scrapers? Let us now specifically address this question.

\section{Discussions}

\section{Variability or diversity in shape?}

The functional consistency of the end scrapers corroborates previous results from the techno-economical and morphological study of the pieces (cf. supra). On the other hand, at this stage of the analysis, it is important to determine why these end scrapers, presumed to be similar from a functional viewpoint, present such marked variability in shape from one piece to another? If these end scrapers really played the same functional role, as we believe they did, then their inter-individual differences, which are at times very pronounced, present a priori a problem. As we just proved for some pieces, prehistoric groups primarily made end scrapers to obtain sharp edges and then sought to preserve this sharpness throughout use. The fact that twelve used end 
scrapers clearly display disparate sharpness (especially in relation to the angle of the working edges) thus appears to be paradoxical in relation to the displayed functional consistency.

However, the aforementioned observations could provide a logical explanation for this. The resharpening operation on most of the end scrapers with traces means that we must consider these tools from a dynamic viewpoint, and thus rethink the static vision presented earlier (cf. supra). Resharpening consumes matter and thus has a direct influence on the degree of consumption of the blank. Although it is up to the craftsman to control the sharpness and the angle of the cutting edge during resharpening sequences, this equilibrium becomes more and more difficult to maintain when the working edge recedes into the increasing thickness of the blank (this is especially true of working edges in an axial position; cf. supra).

Let us thus check the working hypothesis whereby the action of resharpening would lead to the morphological variability of the working edges.

For four end scrapers, which refit onto their original cores, it is possible to accurately measure the degree of consumption of the blank. It appears that the angle of the working edge of these scrapers increases with the degree of consumption of the blank (fig. 9).

Figure 9 - Relationship between the degree of transformation and the working edge's angle. Measurements taken from 10 endscrapers from Canaule II.

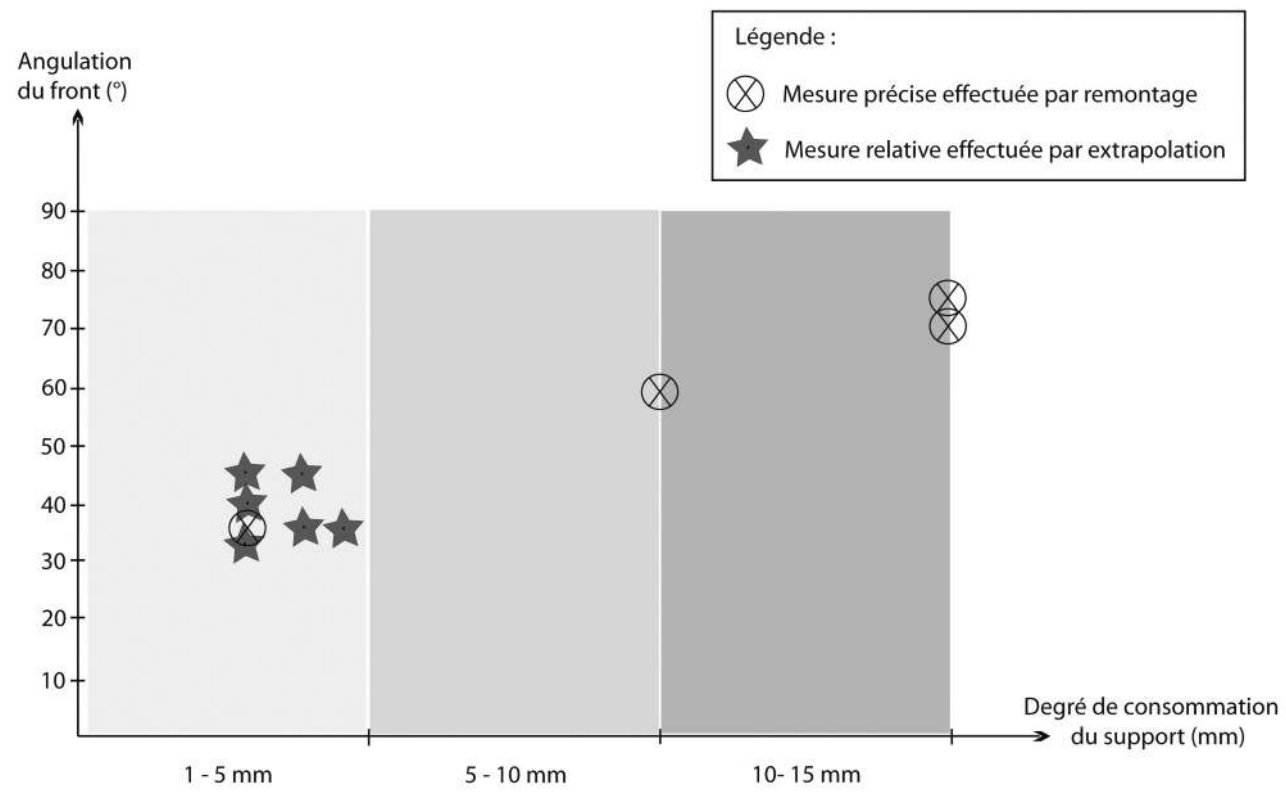

We are conscious of the small number of pieces taken into consideration here and we thus added six working edges with very light retouch (the convergent edges are stopped by this retouch over a small width), allowing for a reliable extrapolation of the total original outline and thus for a reliable assessment of the degree of consumption. (fig. $1 \mathrm{n}^{\circ}-1-,-3-,-5-$ and -6-). Although it is essential to be cautious with such extrapolation, it nonetheless seems that the data from these six pieces confirm our initial hypothesis. 
59 For these six working edges, and for one of the refitted end scrapers, the degree of consumption is about $4 \mathrm{~mm}$ on average and edge angles are systematically acute. For at least four out of these seven edges, which bear remnant zones spared by resharpening, we can thus affirm that the tools were processed in the following way: initial retouch used up $2 \mathrm{~mm}$, followed by light use which did not use up additional matter but involved the light blunting of the working edge, resulting in resharpening, consuming a further $2 \mathrm{~mm}$. It is important to note that the deliberately low-angled retouch maintains the low angle during resharpening. In this way, the prevailing rule here was to optimize the resharpening as much as possible by consuming a minimal amount of matter. Moreover, experiments suggest that a correct resharpening sequence can generally be limited to consumption of 2 or $3 \mathrm{~mm}$ (Caspar and Cahen 1987; Morrow 1997). Whether or not the three other working edges were used, it is now clear that they followed the same rule. Therefore, these seven working edges are all at the very beginning of their functional life.

60 Conversely, for the three other refitted end scrapers with degrees of consumption of 10 $\mathrm{mm}, 15 \mathrm{~mm}$, and $15 \mathrm{~mm}$, the angle of the working edge is respectively semi-abrupt and abrupt for the other two. In addition, the irregularity of the delineation of the working edges (in plan) is, in our opinion, symptomatic of extreme resharpening. These three end scrapers do not bear use-wear traces anywhere else. We are thus inclined to deduce that this is due to the last intensive resharpening sequence, which would not have been followed by another working session. For us, a decisive argument validates this hypothesis. It concerns another end scraper (in chalcedony; fig. $1 \mathrm{n}^{\circ}-11-$ ) with very comparable morpho-functional aspects to the three specimens in question: the thick working edge is truncated in plan and in profile, and the edge has lost all its sharpness owing to the abrupt retouch. The only visible use-wear consists in an isolated spot of polish at the top of the retouch scars. We saw above that this end scraper simply corresponds to an adaptation of the gesture by the user, aiming to compensate for the probable lack of sharpness of the over abrupt working edge. Thus, not only was this end scraper resharpened until it was worn out, it was also used to its utmost (that is for as long as the sharpness of the working edge was still apt for thinning hide). Furthermore, the ethnographic (e.g., Clark and Kurashina 1981, p. 308; Albright 1984, p. 58; Hayden and Gargett 1988) and archaeological records (Semenov 1964, p.87; Rigaud 1977; Jardòn and Sacchi 1994; Rots 2002; Bon and Mensan 2007) confirm that repeated resharpening sequences are usually accompanied by a distortion of the original working edge, i.e., by irregularity in plan and an excessive opening of the working edge angle.

61 The end scrapers from Canaule II with a distorted and abrupt working edge can thus be interpreted as depleted tools, probably after one or several phases of use and resharpening. However, the exact number of these rehsarpening sequences (and thus use) is more difficult to infer than for discrete working edges. It is impossible to know whether the prevalent rule at the beginning of the functional life of the piece (i.e., retouch affecting 2 to $3 \mathrm{~mm}$ for each resharpening sequence), was applied throughout the life of the tool, until its depletion. It would thus be misleading to make any conclusions in that respect.

Given the amplitude of certain retouch removals on these worn out resharpened working edges, some of which are resolved, indicating that various accidents occurred, the craftsman would have had to adapt in such critical cases, by using up less matter. 
Nonetheless, considering the rule of minimal consumption of matter at Canaule II, we can estimate that the three abrupt end scrapers refitted onto their cores underwent between four and six possible resharpening sequences. This must be taken as a maximum upper margin. As a consequence, at least seven other end scrapers including some with use-wear traces - can be associated with these tools. They also present working edges distorted by sequences of clearly repeated retouch, but the edges indicate that the degree of consumption was probably only around one or two centimetres (fig. $1 \mathrm{n}^{\circ}-1-,-2-,-3-,-4-,-5-,-7-$ and -10-).

As for the five other end scrapers with a notched resharpening scar (cf. supra), it is fitting here to briefly question their functional lifecycle. In response to the first question, consisting of evaluating the angle of the working edge just before the notch was made, only two pieces are in a position to provide an answer. These are, on one hand, the only reharpening notch found (fig. $6 \mathrm{n}^{\circ}-3-$ ), and on the other, the end scraper $n^{\circ}-57$ I3 (fig. $6 n^{\circ}-1$ ), abandoned just after the notch was made due to the fracturing of the piece (cf. infra).

In both cases, the working edge is semi-abrupt ( $70^{\circ}$ for the first and $55^{\circ}$ for the second). Secondly, owing to the fact that end scraper $n^{\circ}-57$ I 3 refits onto the core, it provides us with information on the degree of consumption of the blank just before notching. This was $6 \mathrm{~mm}$. Thirdly, the five working edges with a notch all illustrate that the degree of consumption of the blank after the notch is very slight (fig. $\left.6 \mathrm{n}^{\circ}-2-\right)$, consisting in a single row of relatively marginal retouch and corresponding exactly to the slight resharpening identified on certain end scrapers. All these elements imply that resharpening by notches intervenes around mid-stage in the functional lifecycle of the tool, after the production of a more gradually evasive working edge by several series of retouch (sharpening and resharpening), and the previous cycle can then be repeated identically after the notch. In sum, whether the notch accentuates the front of the end scraper or individualizes two narrow fronts, its main role is to revive a cycle at Canaule II, mid-way during the functional lifecycle of the tool. The process is destined to rearch one or two working edges and to reopen possibilities for controlling the angle. This is also documented in ethnological records (e.g., Clark and Kurashina 1981, p.308).

Lastly, given that our demonstration includes end scrapers with and without use-wear, in our opinion, this provides sufficient evidence to extrapolate our hypothesis to all the end scrapers from Canaule II. Nonetheless, it is important to underline that this extrapolation must be treated with caution as it was impossible to measure the degree of consumption for most of the end scrapers.

Ultimately, all these tools would have been made to comply with the same modalities of technical maintenance. They would also have been abandoned at different stages in their functional lifecycle.

If we compare this new information to the high functional consistency observed for twelve pieces, we can conclude that the end scrapers from Canaule II correspond to the same variability for the same type of tool. Although this variability is intrinsic to the series (cf. supra the techno-morphological study), it is accentuated on the working edges by the extrinsic resharpening factor.

However, a paradox remains, which will be discussed below in the experimental approach. This is, even if the morphometric analysis of the working edges did not identify the existence of a particular category, it showed that the Chatelperronians 
consciously made some of the end scrapers with narrow fronts, and that they deliberately maintained the arc of these pieces throughout their functional lifecycle.

Thus the question of the possible diversity of types is raised once again; it is easy to imagine that a subtle observation escaped our morpho-functional analysis and that only the experimental approach, presented below, can shed light on this question. We will thus come back to this point later.

70 It is now necessary to make a detour by means of the spatial analysis of the end scrapers in order to shed light on the general management modalities of these pieces in the excavated zone.

\section{A spatial analysis detour}

71 The analysis of the spatial distribution of the end scrapers shows that they are nearly always outside or on the edge of the main lithic concentrations, or systematically in the case of the end scrapers with use-wear traces (fig. 10). The end scrapers are not clustered in the same zone, but rather appear to be randomly dispersed throughout the site. But this observation is immediately questioned by several significant facts. Firstly, about a third of the end scrapers with use-wear traces, as well as three others with no use-wear, are clustered in square G3. If we add the adjoining squares H3, G4 and H4, the total number of end scrapers in this zone makes up a third of the whole collection, whereas the number of end scrapers with use-wear goes up to more than half of the 12 known pieces. Secondly, the south of a very confined and isolated zone with five end scrapers, all in chalcedony, contains more than half of the end scrapers in chalcedony, three of which bear use-wear. Lastly, the end scrapers with use-wear are more often surrounded by several other end scrapers, with or without use-wear traces. These points represent general observations, but the details reveal another whole range of information. In these two concentrations, when we look more closely at the end scrapers bearing use-wear, we observe that some of them are in the early stages of their functional lifecycle (e.g., fig. $1 \mathrm{n}^{\circ}-3-$ ), whereas others display considerable receding of the front (fig. $\left.1 \mathrm{n}^{\circ}-2-,-3-,-4-,-5-\right)$, when they have not been worn out by resharpening (fig. $\left.1 \mathrm{n}^{\circ}-7-,-11-\right)$. The Clactonian retouch flake with use-wear is also present. If we add the end scrapers with no use-wear present in this zone, this pattern is confirmed, as shown by the very depleted notched end scrapers (fig. $6 \mathrm{n}^{\circ}-2-$ ) and others with a more discreet and lower-angled front. The same pattern occurs in reduced format in at least three isolated units at the edge of the site. In this way, in the northeast of the site (square J1), there is a group of three end scrapers, two of which bear use-wear traces, one of which was prematurely abandoned after a single resharpening sequence (fig. $7 \mathrm{n}^{\circ}-2-$ ), while the other was only slightly used after being notched and is probably at the end of its functional life cycle. At the west of the site (squares C-D5) the same situation occurs, although here the second end scraper does not bear any use-wear traces; it displays perfectly controlled thin, invasive retouch, which consumed a non-negligible quantity of the blank, in agreement with our hypothesis of a "maintenance cycle" at Canaule II. Lastly, we can see the same situation on three end scrapers with isolated use-wear traces in the north (square F1), one of which bears a discreet and low-angled front, and two others resharpened to a state of total depletion. 
72 In addition, refit $\mathrm{n}^{\circ}-298$ provides a perfect illustration of the processing elements brought to light earlier. After the debitage of a large flake, split into two by a Siret accident, the main fragment remained close to the core, whereas the second was moved about six metres away, to a zone with relatively few lithic objects, where it was used for a short period of time, very lightly resharpened, then discarded immediately afterwards. The other fragment was used just beside the debitage zone, containing small zones with no debitage flakes. The detailed observation of the refit on the original block implies that this fragment was retouched until the widening of the working edge called for slight re-arching by means of a notch (cf. supra and infra). At this stage, the tool was broken into two, owing to the presence of a geode. Although the working edge was still perfectly operational, the user immediately abandoned the smaller fragment (which bears no trace of use after the fracture), probably because of its small dimensions. On the other hand, its counterpart was moved about a metre away (still at the edge of the main concentrations) where it was heavily retouched until the working edge lost its acuity and became too irregular in plan. According to our hypothesis (cf. supra), we can thus consider that this end scraper was repeatedly used and resharpened, but that like for the other pieces, it underwent a resharpening sequence that removed the use-wear traces before being discarded.

There are thus several small spatial activity units where one or several end scrapers were used then abandoned at different stages of their lifecycle. These end scrapers would have been selected from the pile of debitage then moved to the above mentioned units. They probably did not undergo further on-site movement until the end of their functional lifecycle.

74 It is reasonable to assume that this is the proof that tool rotation was applied in each unit, and that tools were replaced as soon as they reached depletion stage. As a consequence, we can suggest that each small spatial activity unit was used to work a distinct hide element (although we cannot specify whether this occurred simultaneously).

This spatial information thus allowed us to understand, at the same time, both the significance of these small work units and that of end scraper management. For us, this provides ample proof that these tools were made for identical activities, each of which was probably carried out from A to $\mathrm{Z}$ in a separate spatial unit. However, it is not possible to gauge whether or not these activities were synchronous. Besides this new fundamental information, other data emerged, also related to the operative process, allowing us to continue investigations into the exact nature of the latter. However, in order to address this question, it is essential, in our opinion, to first explore another issue. That is, "how much work" was carried out in each unit?

\section{Quantity of work}

By "quantity of work", we refer more to the "use ratio" of the tool than tool productivity (in terms of the number of processed hides, for example). That is to say, the longevity of use in relation to the degree of use (use signifying here both the blunting of the working edge and the degree of consumption through successive resharpening episodes). Inferring this ratio from the intensity of the use-wear and resharpening is an old notion in archaeology, both in the experimental domain and in 
prehistory (e.g., Semenov 1964; Tringham et al. 1974; Shchelinskij 1983; Hayden 2002; Boyd and Pelton 2014).

Figure 10 - Spatial distribution of end scrapers in relation to all the lithic remains (grey = debitage waste); in relation to the morphological and functional data.

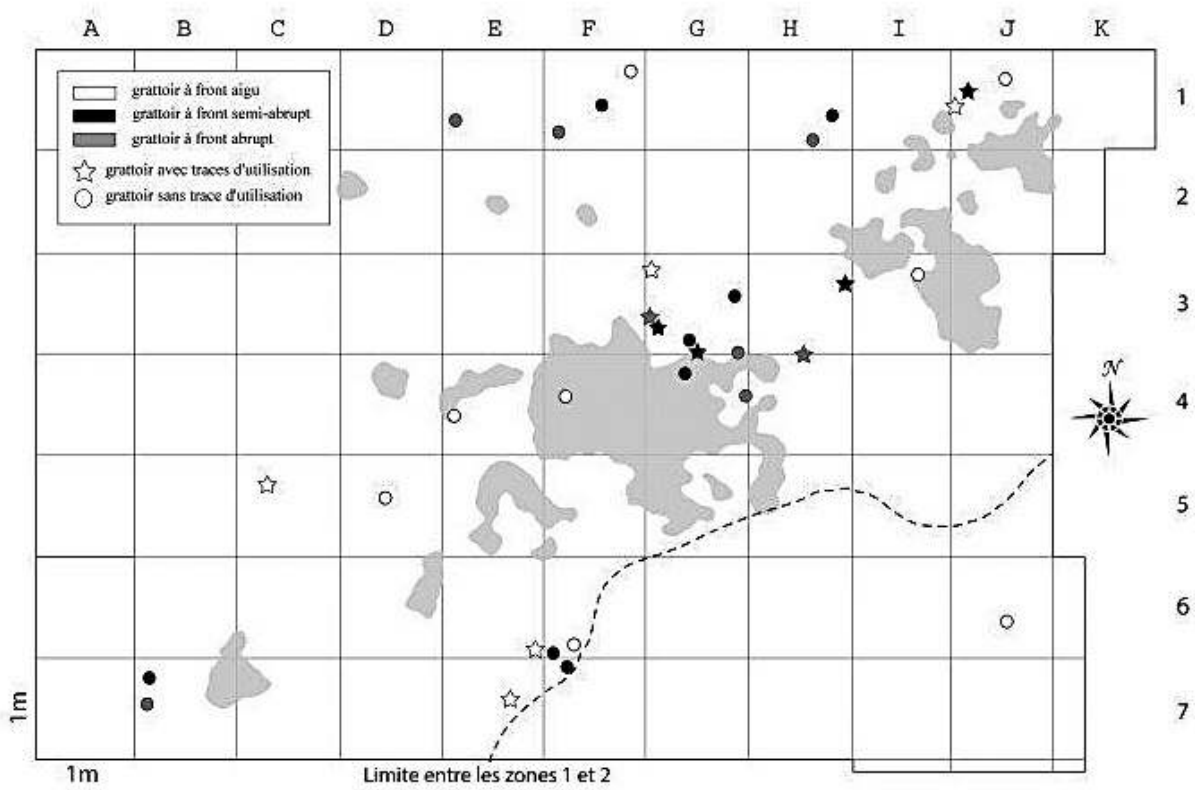

In the domain of hide working, this depends on diverse factors, such as: the degree of humidity or dryness of the skin, the number and size of the processed hide elements, their thickness (which varies according to the animal species, as well as on the age and sex of the specimen), the craftsman's skill, the degree of effectiveness of the tool throughout time (in relation to its shape, weight, angle), i.e., in relation to the different episodes of use and resharpening, and of course, the number of people involved in working on a given hide. It is important to add two essential parameters to this list. The first is the type of activity, and the second is the craftsman's aim to work the whole hide surface, or just part of it. For any given dry hide, the different aims entail different movements and thus different uses of the tool. As for the intervention zone, it conditions the gestures used as hide has a heterogeneous structure, in terms of variations in natural thickness from one zone to another (sides, neck, etc.), and also in terms of accessibility for tools (more or less creased zones, poor tension, or inoperative tanning). This is what we observed experimentally, echoing the conclusions of many former experiments. The same aim of eliminating the hypodermis from dry marten, cervid or bison skins, in order to soften them, involved very different use-wear conformations, waste production, work time and tool maintenance strategies (table 1, cf. Annex).

As far as the species is concerned, the fact that we do not know the relative quantity of processed hide elements, the represented animal species and the total surface worked by each end scraper, is sufficient to dampen the ambition of this paragraph. However, we can still use some solid arguments and deduced extrapolations to advance our investigation. 
us, the information recorded above in relation to the small spatial units of activities and the rotation of tools within them can be applied here. We presented three points above, using examples of end scrapers abandoned at different stages of their functional lifecycle. Firstly, there is the general rule of slight use between two resharpening sequences, with resharpening episodes consuming a minimum quantity of material each time (about 2 to $3 \mathrm{~mm}$; cf. above). Secondly, as soon as the successive resharpening cycle produces an unsatisfactory edge angle, the end scraper is abandoned. We thus suggested that another end scraper would replace it at that stage, referred to as "new", as it was shaped ad hoc and presents the required qualities. Thirdly, given this information, we deduced that most of the end scrapers with a totally distorted working edge could only have accumulated four to six active working episodes until the end of their functional lifecycle, interspersed by an equivalent number of resharpening sequences. When put together, this information provides an acceptable working hypothesis for the two zones of end scraper concentrations, as well as for the three small separated units in squares J1, C-D5 and F1 (cf. supra).

The central unit, with seven more or less heavily consumed working edges and six presenting signs of more discreet consumption, as well as a retouch flake with welldeveloped use-wear, must altogether have accumulated about fifty scraping sequences. As for the south unit, containing two pieces with discreet working edges and four with relatively slightly consumed working edges (although with a higher degree of consumption than the two former pieces), including one with particularly well developed use-wear, it must represent about twenty scraping sequences. The smaller units cited as examples earlier probably did not exceed five scraping sequences.

81 This simple simulation exercise, which is deliberately overstated, merely aims to evaluate the upper bracket of the total quantity of work. If these estimations are compared to the fact that most of the working edges with use-wear traces (regardless of their lifecycle stage) only present slight use-wear, we can then grasp a relatively realistic idea of the quantity of work carried out by these end scrapers. This quantity is thus quite low for each tool. In order to comprehend the validity of this association, and before a more detailed discussion of this point in the discussion below, we now wish to introduce a useful benchmark for novice readers in hide working matters. A light scraping of dry hide, in terms of the force applied to the action or in terms of the duration of use, requires at the best of times about ten end scrapers, about half of which are used until they are worn out. Cumulatively, this operation entails about fifty sequences of light action, interspersed by episodes of resharpening, and only results in the full treatment of a small surface of the hide (e.g., Boyd and Pelton 2014). Before developing the exact nature of the activity conducted in each unit, which is the only information liable to provide accurate data in relation to the aforementioned tendency, let us conclude here that at the very least, only a small total surface of hides were processed in each unit. In addition, the cumulative quantity of work must also have been low, in spite of the fact that this activity was shared by different operators at the site and that the worked materials were for the group as a whole (as opposed to the idea that each worked element corresponded to an individual and marginal need). 


\section{Nature of the activity}

82 From here on, we will take it for granted that the end scrapers from Canaule II were used to scrape dry hide, which was probably stretched, contained no humidity, but was sometimes slightly fatty, with no additives. The motion was regular, with a handheld end scraper, with the upper surface striking the hide and a constant clearance angle of about $60^{\circ}$. The working edges were resharpened as soon as the slightest signs of blunting set in, by direct handheld percussion, apart from one case of prolonged use with no final resharpening. Overall, only a small hide surface was worked in each spatial activity unit.

Does this information enable us to deduce the exact nature of the activity, or to situate it within an assumed operative sequence?

Let us analyze one by one the main possible scenarios for dry hide working, and assess which of them can be retained here. We will base this discussion on the extensive, but not exhaustive ethnographic literature concerning nomadic groups carrying out traditional hide processing with stone tools. It is essential to bear in mind that this is, by nature, qualitatively asymmetrical, with on one hand, "simple" travel accounts, mostly dating from the second half of the 19th century and the beginning of the 20th century, and, on the other, investigations conducted over the past decades by ethnologists or prehistorians aiming to establish an accurate record of the details and gestures involved. For tool resharpening, for example, which is of major interest to us here, we did not find enough detailed references, but especially references that could be transposed to our context. The reason for this is that a lot of these studies were conducted recently in East Africa (e.g., Gallagher 1977; Weedman 2002), where most of the groups use obsidian end scrapers, a raw material that does not react like flint to use, wear or retouch (a fortiori when a metal retoucher is used to retouch the tool). Among these groups, the Konso are an exception to this general rule and some comparisons can thus be made (Brandt and Weedman 2002; Rots and Williamson 2004). We also base this discussion on recent work in North America (Beyries 2008). More generally, to compensate for this problem, we will also refer to archaeological experiments, and in particular our own, when we consider it necessary.

Fleshing is a necessary first step and can be carried out by scraping when the skin is dry. Nonetheless, as this operation is considered to consist of the superficial cleaning of the fat and muscle adhering to the skin (flesh side), this stage can also be conducted on fresh skin (or resoftened skin), by cutting it with an ordinary cutting edge. There is no need to cut into the skin to thin it. This stage is quite fast (never more than half an hour). Depending on the surface of the dry skin, the way it is mounted, the way the tool is held (hafted or handheld), and the force applied to the action, the use-wear at the end of the operation is thus of average intensity. Waste only consists of dry heaps, then, once the hypodermis has been attained, of powder (table 1, cf. Annex). In all cases, it does not require a particularly sharp working edge, or resharpening. On the contrary, a blunted working edge is ideal so as not to cut into (or even scratch) the layers of skin. Thus the degree of consumption of the blank does not vary between the beginning and the end of this stage. The incidence of the cutting edge is of little importance, giving the craftsman free rein. Often the ethnographic literature does not distinguish clearly between simple superficial cleaning and the thinning of the hide itself (e.g., Harrington 1957, p. 70-72). Consequently, the rare mentions of resharpening 
cannot be considered as resharpening episodes in the strict sense of the term. It is important to note that fleshing is only sufficient in itself when a simple final end product is sought after (the operative sequence referred to as "zero degrees"; cf. Hayden 2002), and ends with the direct use of the hide, known as "raw" (for example: for use as mats, tents, etc; cf. Balikci 1970, p. 8; Turner 1979, p.151-155). On the other hand, hide thinning, which involves the total elimination of the hypodermis, and even cuts into part of the dermis, is an activity that penetrates into the skin and produces very controlled shavings. It can thus take quite a long time depending on the surface of the skin. It requires a sharp cutting edge, and does not tolerate the slightest blunting, thereby necessitating frequent resharpening. Thus usewear is slight at the end of each active sequence. We reproduced the archaeological use-wear exactly by thinning the flesh side of a dry bison skin stretched on a convex block, and by resharpening the working edge when it was totally ineffective, after about 10 minutes work (cf. infra). This implies that this gesture, considered by Jacques Chapat to be the most effective, was also used by the craftsmen at Canaule II. It consists in pulling the tool with the upper surface towards him, with an intermediary working angle (of about $60^{\circ}$ ), holding the tool with both hands: the tool is held in the palm of one hand while the other hand supports and guides the first (fig. $8-2 \mathrm{a}$ and $2 \mathrm{~b}$ ). The particularly developed use-wear observed on one of the archaeological specimens was replicated during experimental work by using the same gesture, but by using the tool for a further 10 minutes after the first signs of blunting appeared.

However, we can point out a single example of a slightly blunted end scraper used without resharpening to thin dry, relatively thin hides by the Netsilik in the ethnographic literature available to us (Balikci 1970, p.8). A wide, convex working edge is not appropriate for this action since the energy must be concentrated in one point to be effective. This observation has been formulated by many experimental workers before us (e.g., Shchelinskij 1983, p.124-133). The degree of consumption of the blank varies from the beginning to the end of this stage, but is directly correlated to the thickness and the surface of the processed skin. This is confirmed both by experimental operations and ethnographic observations. During our experiments with the craftsman, the thinning of a whole red deer skin (only the hypodermis), placed on a table with no stretching system other than the body, worked with a handheld end scraper, did not require any resharpening. Conversely, the same action with a handheld end scraper, on a dry bison hide, required slight resharpening every 10 minutes, or every several hundred strokes, as well as a smooth and convex base (or strong stretching on a frame). The duration of the lifecycle of an end scraper is thus equivalent to eight activity sequences, leading to an overall retreat of the working edge of a little more than $2 \mathrm{~cm}$.

Yet, this "constraint" is exclusively due to the fact that the craftsman must initiate, then remove a long shaving across this extremely hard material. After the first signs of blunting after 10 minutes work, the working edge begins to slip without cutting into the skin, only producing powder. Increasing pressure on the skin, or increasing the angle of the gesture does not change anything.

Let us also cite the experimental work of J. Wiederhold (2004), a seasoned craftsman who worked bison hide. This hide was not totally dry, which means that it was not as rigid as ours. For the same action as ours and the same effectiveness (producing long shavings), he only felt the need to retouch his working edge after 2,700 strokes, which is a very superior duration to ours (op. cit., p. 76). We can also cite the ethnographic 
example of the Konso groups in the south of Ethiopia, who, unlike in our experiments, resharpen their working edges relatively frequently during the thinning (on the flesh side of the hide) of fine dry hides (Brandt and Weedman 2002; Rots and Williamson 2004). However, neither the rocks used nor the use-wear traces are comparable to our context. We can also cite the Athapaskan Indians, who thin fine dry skins stretched on a frame, on the pelt side so that they remove the hair at the same time. Again, in this case, resharpening is frequent (Beyries 2008, Diaporama Modélisations). But the polish generated is not at all similar to the use-wear on our archaeological end scrapers. To a lesser extent, we could also evoke the Caribou Inuits, who thin their averagely thick skins with sharp, occasionally resharpened endscrapers (Michéa 1949, p. 38).

Thus, thinning fine skin (such as cervid or equid skin) is different from thinning thick skin (such as bovid skins for example, or some exceptionally robust suids or cervids). Firstly, in regard to the properties of the two types of skin: the hypodermis of thick skin is harder than that of fine skin. The considerably different levels of force required at the beginning of thinning can lead to different resharpening frequencies in both cases. Secondly, both of these hides fulfil different objectives. Fine hides do not necessarily require dermis thinning as natural lubricants penetrate easily into them, whereas for thicker hides, this is not the case. In this way, the thinning of fine hides generally corresponds to a resolve to obtain a fine end product for a specific purpose (e.g., drum, manufactured object, etc.; cf. Beyries 2008). Although the thinning of thicker hides can also target similar objectives (for example in Patagonia, cf. Casamiquela 1978; in the north of America, cf. Damas 1984, p. 449, or the Copper Inuits, cf. Harrington 1957, p. 70-72), it generally involves processing (example of the Athapaskans, cf. Beyries 2008; certain Sioux, cf. Hassrick 1964, p.217-219) aiming to improve flexibility (a property more generally lacking than in fine hides). In any case, these two types of hide processing have two points in common. Both of them require considerable savoir-faire to thin the hide in a consistent and calibrated way, without ever piercing it. And both involve a more or less complex and demanding operative sequence, representing a genuine craft.

91 Dry hair removal consists in removing the fur and the epidermis that the fur adheres to (more or less deeply depending on the species; cf. Chahine 2002) with the same motion. It is thus similar to thinning in that the dermis is exposed, or even cut into. This is the only reason for carrying out this operation in a dry state, given that the use of natural chemical processes (controlled rotting, soaking in ashes, etc.) is much more parsimonious in terms of time and energy. Thus we sought to assess whether dry hair removal is more frequent on thicker skins and too risky on finer skins (the latter being systematically soaked first and then de-pelted while still humid). We tested this experimentally on bison skin. This required tight mounting on a frame so that the tool could bite into the epidermis through the high density of fur without being hindered. As the skin is not greasy, we cannot use this argument to explain the sliding of the tool on the fur. This reason is however invoked in ethnographic accounts of the Athapaskans, who remove fur from large dry bison skins, mounted on frames (Beyries 2008, p.30). Several movements were tested in order to avoid this and one of them compensated for this problem. It consists in using the off-centre part of the working edge. In this way, the tool and the hand are both slightly offset in relation to the worked zone, which presents two decisive advantages. The first is that the worked zone is visible as the previously worked bands can be used as contact zones to be worked from. The second is that it is possible to cut into the next shaving from this contact 
zone. To do this, the use of end scrapers on large flakes was complicated and ineffective, whereas the use of short flakes/blades proved to be impossible. In all cases, the unsurmountable constraint stemmed from a combination of three simultaneous problems. Firstly, the density of fur hinders the contact of the cutting edge with the epidermis. This problem was not totally resolved, even with a prior shaving test (on a zone) of the fur. This directly explains the second problem, which is the extreme difficulty in keeping a rectilinear trajectory during the movement. And lastly, the lack of strength applied to the working edge as the hand does not procure a lever effect (procured by a handle), the flake is short and the tool frequently slips. Only hafted end scrapers on blades are effective for this task, using the corner of the distal part, that is the lateral part of the arc, or the centre of offset working edges (fig. 8 -1a-).

This configuration was the only effective one as it fulfilled all the inevitable technical requirements: a narrow and extremely sharp working edge is necessary in order to cut into the epidermis; whereas the use of the offset part of the blank allows for the control of the power and the trajectory of the tool; lastly the hand is sufficiently far from the worked material to generate a sufficiently powerful lever effect. The required time for slight use-wear of the working edge (which nonetheless impedes efficiency) is reduced by half in relation to thinning on the flesh side of the hide. This can be explained by the fact that the tool is much less tolerant to the slightest softening when the layer of fur is present. Resharpening was thus technically essential every five minutes, resulting in a slightly developed polish at the end of each sequence, similar in all respects to that of a single archaeological piece, apart from its offset location on the experimental tool. Lastly, the removal of the epidermis and the hair required a blade with a thinner distal part and thus a more acute working edge, compared to thinning of the flesh side. But the working movement necessarily involved an open angle and thus more developed use-wear towards the retouch scars on the upper surface of the tool. Although the polish is qualitatively similar to the archaeological polish, polish distribution is different. As for the degree of consumption, resharpening every five minutes led to the rapid discarding of the handheld tool. This is due to the retreat of the working edge and the excessive widening of the angle.

If we compare these results with ethnographic records, two observations related to dry hair removal from bison skins by the Indians appear to be particularly relevant. The Athapaskans frequently sharpen their end scrapers during this activity (with hides stretched on a frame) and the tool is replaced when it becomes too short after successive resharpening epsiodes (Beyries 2008, Diaporama Modélisations). Certain Sioux scrape (hides stretched on the ground) using stone end scrapers, but we have no information on prehension or resharpening frequencies (Hassrick 1964, p. 217-219). In any event, it is clear that dry unhairing requires great skill and is also technically demanding as far as the tools are concerned. It is characteristic of operative sequences geared towards specialized products (e. g., belts, cf. Balikci 70, p. 9; summer boots, cf. Turner 1979; aprons, cf. D'Iatchenko and David 2002). As it also makes it possible to process skins right through to the core (in terms of depth), it is also typical of prolonged operative sequences, leading to the production of very supple articles.

Treating hide through to the core is by nature a chemical process, and although it involves a mechanical component that consists of rubbing in substances to penetrate the dermis (e.g., Robbe 1975), it does not include the use of active tools (such as end scrapers, etc.). Prehistoric proto-tanning methods, like those of sub-contemporaneous 
ethnographic populations (when used; cf. Robbe 1975; Ours Debout 1980; Beyries 2008), must have been fast, in keeping with a nomadic lifestyle (e. g., Hayden 2002). They could thus consist in coating the hide with grease with special qualities, which could penetrate into the hide, whether it was dry or soaked (ibid.). Although we did not find any mention of the use of end scrapers for this stage in the ethnological literature at our disposal, we nonetheless conducted an experimental test using brain tissue. It transpired that the work was completed after about 30 minutes (all the brain was absorbed) and that the final use-wear on the tool was strong (table 1, cf. Annex). No sharpening was required as the hide was not thinned. The polish is qualitatively midway between a humid hide polish and a dry hide polish (e. g., Plisson 1985), and is thus very different to the polish on our archaeological end scrapers.

The softening or bating stage intervenes after this process. The processing of the inner skin (when used) occurs during the drying stage, to prevent the fibres from retracting during drying (e.g., Chahine 2002). This is the case for the thick skins processed by the Athapaskans, for example (Beyries 2008). Nonetheless, as this work continues for days until the hide is completely dry, with no sharpening of the tool, the final use-wear is very strong and is only made up of dry hide polish (ibid. Diaporama Modélisations). For the other cases, when the hide is completely dry, such as all those cited earlier, we did not find any mention of the use of end scrapers at this stage in the ethnological literature. However, it would have a role to play, in the same way as the Athapaskan "softening end scrapers", in breaking the dermic fibres to make the hide more supple. This was tested experimentally, with no required sharpening (table 1, cf. Annex), and produced the same use-wear traces as those on the "softening end scrapers" used by the Athapaskans. Once again, these bear no relation to the use-wear traces on our archaeological end scrapers.

Lastly, regardless of the contexts4, skin types, and the fact that they are raw or tanned, a constant universal technique intervenes at the very end of the process. This is finishing the softening of the edges of the hide. These zones are difficult to access with tools and natural lubricants, and as the fibres tend to agglomerate here, they need to be broken so that these areas can be softened. We did not find any mention of end scrapers for this task in the literature, but abrasive pebbles were used in some cases (e.g., Beyries 2008, p. 33). In addition, our experimental test with an end scraper did not require any sharpening (tab. 1 , cf. Annex).

97 The finishing stages, i.e., making objects with totally dry hide, could also require end scrapers. For example, the adjustment of some leather parts, in particular (e.g. Robbe 1975 and Robbe in oralis cited in Plisson 1985; Turner 1979, p.58; Damas 1984, p.449; Beyries 2008), that could justify the use of a sharp cutting edge and maintenance by frequent resharpening. But we did not come across any such mention in the available ethnographic literature.

In the light of all these considerations, the configuration of the end scrapers from Canaule II appears to be compatible with thinning dry hide of a certain thickness (several millimetres). The processed skins must have been modest in size in each unit, whether they were fully thinned or simply evened out in places. We did not establish which side of the hide was processed. Even so, this would not have fundamentally changed the fact that we cannot pinpoint the exact stage that this represents in the overall sequence. Although we are sure that it was not an early stage, it could, on the other hand, represent a mid-stage operation (if the elements were then further 
processed) or a final stage (if they were directly used or manufactured). However, we can conclude that this operation represents a specialized segment of the already welladvanced leather processing sequence, and is potentially a key element of this process and a very specific operation. As for the functional purposes of this production, we have no indications whatsoever.

(4) Jacques Chapat himself, in spite of modern techniques consisting in long tanning baths in chemical solutions, must use twice as much effort to soften these zones.

\section{Conclusion}

100 Considering our initial aims, the results of this investigation fall short of expectations, as we have given a detailed account of the tools and the aim of the activity carried out, whereas we have no means of knowing its real significance. As the end products of these sequences have not been preserved, and the degree of resolution of our analyses did not allow us to identify their exact nature, we lack capital information concerning the functional purpose of the production sequence. And this is the key to understanding the technical system. Thus, a whole sector of our discussion cannot be assessed here; that is, the role of leather working in the economy of this Chatelperronian community. Taking this into consideration, we must, as is often the case in our discipline, look at the "mineral skeleton" (to use one of Jacque Tixier's expressions) of this activity, and make do with the technical and economic information inferred from this study. Let us recapitulate.

End scrapers occupy a secondary position in the technical lithic system at Canaule II, in relation to the production of blades, but nonetheless play an important role. First of all, if we consider the value of the by-products of the end scraper blanks, they take a backseat to the central and almost exclusive production of Chatelperron blanks. The only intention that emerges here concerns blank selection, and thus intervenes after the debitage. Large flakes are preferentially chosen, clearly made up both of elongated and non-elongated products. Let us consider also, the presumed absence of a hafting system, at least for most of these end scrapers, which demonstrates, once again, the low degree of technical investment involved in the manufacture of these tools.

Lastly, we could also assume that the activity that these tools were used for must not have been of any major economic importance. Here, we demonstrated that the remaining tools were not intensively used for leather working, and we can also add, on the basis of this study, that productivity at this site was low, and did not involve large scale leather manufacture. However, it is important not to minimalize these tools or the activity that they were used for at the site. This would first of all be an unspeakable shortcoming as it would represent a purely theoretical shortcut (Sigaut 1991). It would undeniably be a prime example of the ethnocentric reasoning of our industrial society to consider that this activity did not count for much in the economy of this occupation, solely on the basis of a presumed low degree of leather production. It would even preclude, without any solid foundations, the fact that leather might be a symbolic material and that leather working may be important in other ways, apart from in the routine of daily life and in terms of productivity. For a more prosaic reason, all that would be even more audacious given that doubts subsist as to the extension of this occupation, following the discovery of Chatelperronian remains in stratigraphic position, about thirty metres from Canaule II (L. Bourguignon and I. Ortega, pers. 
comm.). Lastly, more concrete arguments emerge from our study, proving that this activity was important for the community. We are referring to the fact that the Chatelperronians made more than thirty typologically well-defined end scrapers, with specialized functions, and that these tools were then used in demanding ways. And also to the fact that the hide thinning activity carried out at the site required great skill. We will now expand upon these two points, which, in our opinion, make up the main conclusions of the present study.

103 First of all, we are struck by the consistency of the use patterns and the maintenance patterns at the site; in sum, by tool management, which is equivalent for the whole series. These end scrapers are the exact opposite of "disposable tools" or "occasional tools", conceived for use for an immediate and once off requirement, and displaying an extravagant attitude towards the raw material. Conversely, the almost invariant use pattern observed for these tools from one operator to another, and their perfectly adequate design (sensu Bleed 1986) in relation to their functional aim (removing long shavings by cutting into the relatively hard superficial layer), show that their conception was perfectly reasoned. In spite of clear shape variability, we effectively brought to light, first of all, that the underlying conceptual patterns (sensu Rabardel 1995) were the same. And this applies both to the thinning motion, and to the dynamic conception pattern of the working edges. We reconstructed the ideal pattern for their evolution from their initial use stages, where they were discreet, narrow, low-angled and maintained by deliberately parsimonious sharpening, until the end of their functional lifestyle where they were deformed by successive resharpening, which in some cases consists in a notch in order to maintain a narrow front.

of course, this does not mean that there were no minor variations on an individual scale. In this respect, the question of deliberately offset end scrapers on elongated blanks could be considered as variations. These end scrapers could nonetheless have been held slightly differently, as shown during the experimental thinning of the pelt side of a bison skin, in an action considered to be the closest to that of the Canaule II craftsmen (cf. supra). The only archaeological end scraper, among the "use-wear population", that was held at an angle close to $90^{\circ}$ could also have been an individual adaptation to a work movement (cf. supra). Yet, the fact that different people selected the blanks from the debitage heaps could also provide a logical explanation for all these minor variations. This could explain why the end scrapers used for the same type of activity display such wide variability, particularly as far as the blanks are concerned. Each user would have applied his/her own selection criteria, which may at times have been so subtle that they escape us, or which would require a whole arsenal of means to be brought to light (e.g., right-handed or left-handed laterality, way to grip the tool, etc.). This would also explain why the end scrapers in (imported) Tertiary chalcedony underwent the same treatment as the other end scrapers. The presence of five specimens in chalcedony on the same square metre (three of which bear use-related micropolish) suggests that their user preferred using his own tool kit in exotic raw materials rather than looking for new blanks in the debitage heaps. Perhaps this is the same person that used one of these end scrapers in a very different way from the other users: holding it up at an angle of $90^{\circ}$ ? Ultimately, we would be faced here with a specific case of shared work, where each operator worked following the same shared patterns with the same class of tools, but nonetheless where individual selection displays some variability. 
Secondly, we saw that the activity carried out required great skill and that it corresponds to a specialized segment of real artisanal leather working. It thus provides proof that the stages of the operative sequence could, at least sometimes, be carried out in a specialized way during an occupation of short duration (as appears to be the case at Canaule II; cf. Bachellerie 2011).

It thus emerges that these tools were not produced in an opportunistic way in response to an immediate and one-off marginal need. On the contrary, we think that their ad hoc production and consumption is part of a framework involving an activity planned in advance, and then carried out on the site beside high quality flint sources.

This is also shown by the contribution, on the left bank of the Dordogne River, of the end scrapers and/or the flakes in chalcedony. Our hypothesis would explain why a human group that came to the site mainly to knap and renew tool blanks consumed some of them on site as part of a connected and demanding activity, in terms of time and technology. It is important to recall that such a schema could also have occurred at other periods throughout prehistory, and for comparable occupation contexts, during the Middle Palaeolithic (e.g., Riencourt-les-Bapaume, cf. Beyries 1993; La Folie, cf. Bourguignon et al. 2002) and the recent Palaeolithic (e.g., Barbas III; cf. Ortega et al. 2006).

To broaden the horizon of this study, in the future, an inter-site analysis could determine to what degree this craft developed throughout the territory and what was the logical structure of this partition in relation to 1) the mineral environment governing flint acquisition and management strategies; 2) the environment (climate, plant cover, etc.) directly determining the mass of ungulates (e.g., Discamps et al. 2014) and therefore the strategies of skin acquisition; 3) site function, mobility and, more generally, the techno-economic strategies of these communities.

\section{BIBLIOGRAPHIE}

ALBRIGHT S. 1984 - Tahltan ethnoarchaeology. Archaeology Press, Archaeology department, Simon Fraser University, Burnaby, British Columbia.

ANDERSON-GERFAUD P. 1981 - Contribution méthodologique à l'analyse des microtraces d'utilisation sur les outils préhistoriques. Thèse de 3e cycle de l'université de Bordeaux I. 314 p.

BACHELLERIE F., BORDES J.-G., MORALA A., PELEGRIN J. 2007 - Étude typo-technologique et spatiale de remontages lithiques de Canaule II, site châtelperronien de plein-air en Bergeracois (Creysse, Dordogne). Paleo, 19, p. 259-280.

BACHELLERIE F. 2011 - Quelle unité pour le Châtelperronien? Apport de l'analyse taphonomique et techno-économique des industries lithiques de trois gisements aquitains de plein-air : le Basté, Bidart (Pyrénées-Atlantiques) et Canaule II (Dordogne). Thèse de doctorat de l'université de Bordeaux I, 442 p. 
BAILLET M. 2010 - Étude fonctionnelle des grattoirs de Canaule II (Creysse, Dordogne), site châtelperronien de plein air en Bergeracois. Mémoire de Master II sciences et technologie de l'université de Bordeaux I, 78 p.

BALIKCI A. 1970 - The Netsilik Eskimos. Waveland Press, Inc.

BAR-YOSEF O., BORDES J.-G. 2010 - Who were the makers of the Châtelperronian culture ? Journal of Human Evolution, t. 59, n5, p. 586-593.

BERTRAN P., KLARIC L., LENOBLE A., MASSON B., VALLIN L. 2010 - The impact of periglacial processes on Palaeolithic sites : The case of sorted patterned. Quaternary International, 214, p. 17-29.

BEYRIES S. 1993 - Analyse fonctionnelle de l'industrie lithique du niveau CA : rapport préliminaire et direction de recherche. In: A. TUFFREAU (Ed.), Riencourt-lès- Bapaume (Pas de Calais). Un gisement du Paléolithique moyen. Documents d'Archéologie Française, Editions de la Maison des Sciences de l'Homme, 37, p.53-61.

BEYRIES S. 2008 - Modélisation du travail du cuir en ethnologie : proposition d'un système ouvert à l'archéologie. Anthropozoologica, 43 (1), p. 9-42.

BEYRIES S., ROTS V. 2008 - The contribution of ethnoarchaeological macro- and microscopic wear traces to the understanding of archaeological hide-working processes. In: L. Longo (Ed.), Prehistoric technology 40 years later: functional studies and the Russian Legacy. Actes du colloque de Vérone (20-23 avril 2005). BAR International Series, 1783, p. 21-28.

BLEED P. 1986 - The optimal design of hunting weapons : maintainability or reliability. American Antiquity. 51, 4, p. 737-747.

BODU P. 1990 - L'application de la technique des remontages à l'étude du matériel lithique des premiers niveaux Châtelperroniens de la grotte du Renne à Arcy-sur- Cure (Yonne). In : C. Farizy (Ed.), Paléolithique moyen récent et Paléolithique supérieur ancien en Europe. Actes du Colloque international de Nemours (9-11 mai 1988). Mémoire du Musée de Préhistoire d'Ile-de-France, 3, 1990, p. 309-312.

BOËDA E., FONTUGNE M., VALLADAS H., ORTEGA I. 1996 - Barbas III. Industries du Paléolithique moyen récent et du Paléolithique supérieur ancien. In : E. Carbonell et M. Vaquero (Ed.), The last Neandertals. The first anatomically Modern Humans : a take about the Human diversity. Cultural change and Human evolution. The crisis at $40 \mathrm{ka}$ BP. Université de Rovira et Virgili, Tarragone, p. 147-156.

BON F., MENSAN R., avec la collaboration de ARAUJO IGREJA M., COSTAMAGNO S., GARDÈRE P., MÉNARD C., SELLAMI F., SZMIDT C. et THÉRY-PARISOT I. 2007 - Le site de plein air de Régismontle-Haut : une halte aurignacienne dans les plaines du Languedoc, In : Qui est l'Aurignacien? Aurignac, Editions Musée-forum, cahier 3, p. 53-71.

BORDES F. 1970 - Canaule. Gallia Préhistoire information. Circonscription d'Aquitaine, tome XIII, $\mathrm{n}^{\circ}-2$, p. 503-504.

BORDES F. 1972 - Du Paléolithique moyen au Paléolithique supérieur, continuité ou discontinuité ? In : F. Bordes (Ed.), Origine de l'Homme moderne/The origin of Homo sapiens. Actes du colloque de Paris (2-5 septembre 1969). Editions UNESCO, écologie et conservation $n^{\circ} 3$, Paris, p. 211-218.

BORDES J.G. 2002 - Les interstratifications Châtelperronien/Aurignacien du Roc de Combe et du Piage (Lot, France) : analyse taphonomique des industries lithiques, implications archéologiques. Thèse de doctorat de l'Université de Bordeaux I, 365 p. 
BOURGUIGNON L., SELLAMI F., DELOZE V., SELLEIR- SEGARD N., BEYRIES S., EMERY-BARBIER A. 2002 - L'habitat moustérien de «La Folie» (Poitiers, Vienne) : synthèse des premiers résultats. Paleo, 14, p.29-48.

BOURGUIGNON L., ORTEGA I., SELLAMI F., BRENET M., GRIGOLETTO F., VIGIER S., DAUSSY A., DESCHAMPS J.-F., CASAGRANDE F. 2004 - Les occupations paléolithiques découvertes sur la section Nord de la déviation de Bergerac : résultats préliminaires obtenus à l'issue de diagnostiques. Préhistoire du Sud- Ouest, t. 11, n² 2, p. 155-172.

BOYD J., PELTON S. R. 2014 - A formal model of scraper performance on dry hide. Poster présenté lors de la 36th Annual Conference of the Colorado Council of professional archaeologists (20-23 mars 2012). Glenwood Springs, CO.

BRANDT A., WEEDMAN K. 2002 - The ethnoarchaeology of hide working and stone tool use in Konso, Southern Ethiopia : an introduction. In : F. Audoin-Rouzeau et S. Beyries (Ed.), Le travail du cuir de la Préhistoire à nos jours. Actes des XXe rencontres d'Archéologie et d'histoire d'Antibes, 2001, Antibes, APDCA, p. 131-129.

BREUIL H. 1911 - Études de morphologie paléolithique II - L'industrie de la grotte de Châtelperron (Allier) et d'autres gisements similaires. Revue de l'École d'Anthropologie de Paris, t. 21, p. 29-40.

BRINK J. 1978 - An experimental study of microwear formation on endscrapers. Nat'1 Museums of Canada, Ottawa, $238 \mathrm{p}$.

CASAMIQUELA R. 1978 - Temas patagónicos de interés arqueológico III : la técnica de la talla del vidrio. R.S.A.A., 12, p. 213-233.

CASPAR J.-P., CAHEN D. 1987 - Emmanchement des outils danubiens de Belgique. Données techniques et tracéologiques. In : D. Stordeur (Ed.), La main et l'outil. Manches et emmanchements préhistoriques. Lyon, p. 185-195, (Travaux de la Maison de l'Orient, $\mathrm{n}^{\circ}$-15).

CASPAR J.-P., MASSON B., VALLIN L. 2003 - Poli de bois ou poli de glace au Paléolithique inférieur et moyen? Problèmes de convergence taphonomique et fonctionnelle. Bulletin de la Société Préhistorique Française, 100/3, p. 453-462.

CHAHINE C. 2002 - Evolution des techniques de fabrication du cuir et problèmes de conservation. In : F. Audoin et S. Beyries (Ed.), Le travail du cuir de la Préhistoire à nos jours. XXII ${ }^{\circ}$ Rencontres internationales d'Archéologie et d'Histoire d'Antibes, Editions APDCA, Antibes, 2002, p. 13-29.

CLARK J.-D., KURASHINA H. 1981 - A study of the work of a modern tanner in Ethiopia and its relevance for archaeological interpretation. In : R. Gould et M. Schiffer (Ed.), Modern material culture : the archaeology of Us. New York, Academic Press, Studies in Archaeology, p. 303-321.

COLLIN F., JARDÓN-GINER P. 1993 - Travail de la peau avec des grattoirs emmanchés. Réflexions sur des bases expérimentales et ethnographiques. In : P. Anderson, S. Beyries et M. Otte (Ed.), Traces et fonction : les gestes retrouvés. Actes du colloque international de Liège (8-9 décembre 1990). ERAUL, 50 , p. $105-117$.

CONNET N. 2002 - Le Châtelperronien : Réflexions sur l'unité techno-économique de l'industrie lithique. L'apport de l'analyse diachronique des industries lithiques des couches châtelperroniennes de la grotte du Renne à Arcy-sur-Cure (Yonne). Thèse de doctorat de l'Université de Lille I, 685 p.

D’ERRICO F., JULIEN M., LIOLIOS D., VANHAEREN M. 2004 - Les poinçons en os des couches châtelperroniennes et aurignaciennes de la Grotte-du-Renne (Arcy-sur-Cure, Yonne). Comparaisons technologiques, fonctionnelles et décor. In : P. Bodu et C. Constantin (Ed.), Approches fonctionnelles en Préhistoire. Actes du XXVe Congrès préhistorique de France, p. 45-65. 
D’IATCHENKO I., DAVID F. 2002 - La préparation traditionnelle des peaux de poissons et de mammifères marins chez les populations de l'Extrême-Orient sibérien de langue Toungouze. In : F. Audoin et S. Beyries (Ed.), Le travail du cuir de la Préhistoire à nos jours. XXIIe Rencontres Internationales d'Archéologie et d'Histoire d'Antibes, Editions APDCA, Antibes, 2002, p. 175-191.

DAMAS D. 1984 - Handbook of North American Indians, vol. 5, Arctic. Smithsonian Institution, Washington.

DAYET L., D'ERRICO F., GARCIA-MORENO R. 2014 - Searching for consistencies in Chatelperronian pigment use. Journal of Archaeological Science, 44, p. 180-193.

DEMARS P.-Y. 1994 - L'économie du silex au Paléolithique supérieur dans le Nord de l'Aquitaine. Thèse d'Etat de l'Université de Bordeaux I, 819 p.

DISCAMPS E. SOULIER M.-C., BACHELLERIE F., BORDES J.-G., CASTEL J.-C., MORIN E. 2014 - Des faunes et des hommes : interactions entre environnements et cultures à la fin du Paléolithique moyen et au début du Paléolithique supérieur dans le Sud-Ouest de la France. In : C. Thiébaut, S. Costamagno, E. Claud (Ed.), Transition, ruptures et continuité en Préhistoire. XXVII ${ }^{\circ}$ Congrès préhistorique de France, Bordeaux-Les Eyzies (31 mai- 5 juin 2010), Mémoires de la S.P.F., p. 299-314.

FERNANDES P., RAYNAL J.-P., TALLET P., TUFFERY C., PIBOULE M., SERONIE-VIVIEN M., SERONIEVIVIEN M.-R., TURQ A., MORALA A., AFFOLTER J., MILLET D., MILLET F., BAZILE F., SCHMIDT P., FOUCHER P., DELVIGNE V., LIAGRE J., GAILLOT S., MORIN A., MONCEL M.-H., GARNIER J.-F., LEANDRI-BRESSY C. 2013 - Une carte et une base de données pour les formations à silex du sud de la France : un outil pour la pétroarchéologie. Paleo, 24, p. 219-228.

GALLAGHER J.-P. 1977 - Contemporary Stone Tools in Ethiopia : implications for Archaeology. Journal of Field Archaeology. 4, 4, p. 407-414.

GENESTE J.-M. 1985 - Analyse lithique d'industries moustériennes du Périgord : une approche technologique du comportement des groupes humains au Paléolithique moyen. Thèse de l'université de Bordeaux I, 2 vol., X, 572 p.

GRANGER J.-M., LÉVÊQUE F. 1997 - Parure castelperronienne et aurignacienne : étude de trois séries inédites de dents percées et comparaisons. Comptes rendus de l'Académie des Sciences, Sciences de la Terre et des planètes, 325, p. 537-543.

GRIGOLETTO F., ORTEGA I., RIOS J. 2008 - Le Châtelperronien des Vieux Coutets (Creysse, Dordogne). Premiers éléments de réflexion. Bulletin de la Société Préhistorique Française, XLVII, p. 245-259.

HARRINGTON R. 1957 - Le visage de l'Arctique. Editions A. Michel, Paris.

HASSRICK R.-B. 1964 - Les Sioux. Vie et coutumes d'une société guerrière. Terre indienne, Albin Michel.

HAYDEN B. 1979 - Snap, shatter, and superfractures : use-wear of stone skin scrapers. In: B. Hayden (Ed.), Lithic Use-Wear Analysis. Proceedings of the Conference held at Department of Archaeology, Burnaby, Canada (16-20 march 1977), Academic Press, Londres, p. 207-229.

HAYDEN B. 2002 - L'évolution des premiers vêtements en cuir. In : F. Audoin-Rouzeau et S. Beyries (Ed.), Le travail du cuir de la Préhistoire à nos jours. Actes des XXe rencontres d'archéologie et d'histoire d'Antibes, 2001, Antibes, APDCA, p. 31-38.

HAYDEN B., GARGETT R. 1988 - Specialization in the Paleolithic. Lithic Technology, 17, p. 12-18. 
HUBLIN J.-J., SPOOR F., BRAUN M., ZONNEVELD F., CONDEMI S. 1996 - A late Neanderthal associated with Upper Palaeolithic artefacts. Nature, 381 (6579), p. 224-226.

HUBLIN J.J, TALAMO S., JULIEN M., DAVID F., CONNET N., BODU P., VANDERMEERSCH B., RICHARDS M.-P.

2012 - Radiocarbon dates from the Grotte du Renne and Saint-Césaire support a Neandertal Origin for the Châtelperronian. Proceedings of the National Academy of Sciences, 109 (46), p. 18743-18748.

JARDÓN GINER P., SACCHI D. 1994 - Traces d'usage et indices de réaffûtages et d'emmanchements sur des grattoirs magdaléniens de la grotte Gazel à Sallèles-Cabardes (Aude, France).

L'Anthropologie, 98, 2-3, p. 427-446.

KEELEY L.H. 1980 - Experimental Determination of Stone Tool Uses. The University of Chicago Press, $212 \mathrm{p}$.

LENOBLE A. 2005 - Ruissellement et formation des sites préhistoriques : référentiel actualiste et exemples d'application au fossile. BAR International Series, 1363, Oxford, $212 \mathrm{p}$.

MAÍLLO FERNÁNDEZ J.-M. 2003 - La Transición Paleolítico medio-superior en Cantabria : análisis tecnológico de la industria lítica de cueva Morín. Thèse de doctorat de l'université de l'UNED, Madrid, $547 \mathrm{p}$.

MANSUR-FRAMCHOMME M.-E. 1986 - Microscopie du matériel lithique préhistorique : traces d'utilisation, altérations naturelles, accidentelles et technologiques. Exemples de Patagonie. Cahiers du Quaternaire, 9. $286 \mathrm{p}$.

MICHÉA J. 1949 - Terre stérile. Six mois chez les Esquimaux Caribous. Bloud \& Gay. Existence du Monde.

MORROW J. 1997 - End scraper morphology and use-life : an approach for studying Paleoindian lithic technology and mobility. Lithic Technology, t. 22, p.70-85.

ORTEGA I., RIOS J., IBAÑEZ J.-J., GONZALEZ J., BOEDA E., SELLAMI F. 2006 - L'occupation de l'Aurignacien ancien de Barbas III (Creysse, Dordogne) : résultats préliminaires sur la fonction du site. Paleo, t.18, p. 115-142.

OURS DEBOUT L. 1980 - Souvenirs d'un Chef Sioux. Collection Histoire Payot, 18, 311 p.

PELEGRIN J. 1995 - Technologie lithique : le Châtelperronien de Roc-de-Combe (Lot) et de la Côte (Dordogne). Cahiers du Quaternaire 20, éditions du CNRS, 297 p.

PELEGRIN J., SORESSI M. 2007 - Le Châtelperronien et ses rapports avec le Moustérien. In : B. Vandermeerch et B. Maureille (Ed.), Les Néandertaliens. Biologie et cultures, Paris, 2007, éditions du CTHS, documents préhistoriques 33, p 283-296.

PLISSON H. 1985 - Étude fonctionnelle d'outillages lithiques préhistoriques par l'analyse des micro-usures : recherche méthodologique et archéologique. Thèse de Doctorat de l'université de Paris I. 357 p.

PLISSON H., MAUGER M. 1988 - Chemical and mechanical alteration of microwear polishes: an experimental approach. Helinium, XXVIII/ 1, p. 3-16.

PLISSON H., SCHMIDER B. 1990 - Étude préliminaire d'une série de pointes de Châtelperron de la Grotte du Renne à Arcy-sur-Cure. In : Farizy C. (Ed.), Paléolithique moyen récent et Paléolithique supérieur ancien en Europe. Actes du Colloque International de Nemours (9-11 mai 1988). Mémoires du Musée de Préhistoire d'Ile de France, 3, p. 313-318. 
PLISSON H. 1991 - Tracéologie et expérimentation : bilan d'une situation. In : Archéologie expérimentale. Expérimentations en archéologie : bilan et perspectives. Actes du Colloque à l'Archéodrome de Beaune (6-9 avril 1988). Errance 2, p. 152-167.

RABARDEL P. 1995 - Les Hommes et les Technologies. Approche cognitive des instruments contemporains. Paris, A. Colin, collection U. Psychologie, 239 p.

RIGAUD A. 1977 - Analyses typologique et technologique des grattoirs magdaléniens de La Garenne à Saint-Marcel (Indre). Gallia Préhistoire, 20, 1, p.1-43.

RIGAUD J.-P. 1996 - L'émergence du Paléolithique supérieur en Europe occidentale. Le rôle du Castelperronien. In : O. Bar-Yosef, L. Cavallo-Sforza, R. March et M. Piperno (Ed.), The Lower and Middle Palaeolithic. Actes des colloques IX et X de l'UISPP. Forli 1996, Ed. Abaco, Forli, p. 219-223.

RIOS GARAIZAR J. 2008 - Nivel IX (Chatelperroniense) de Labeko Koba (Arrasate - Gipuzkoa) : gestión de la industria lítica y función del sitio. Munibe, $\mathrm{n}^{\circ}$-59, p 25-46.

RIOS-GARAIZAR J., LIBANO SILVENTE I., GARATE MAIDAGAN D., 2012 - El yacimiento chatelperroniense al aire libre de Aranbaltza (Barrika, Euskadi). Munibe, n -63, p. 81-92.

ROBBE B. 1975 - Le traitement des peaux de phoque chez les Ammassaliuimut observés en 1972 dans le village de Tileqilaq. Objets et Monde, 15, p. 199-208.

ROTS V. 2002 - Hafting Traces on Flint Tools: possibilities and limitations of macro- and microscopic approaches. Thèse de Doctorat de l'université Katholieke de Leuven, 486 p.

ROTS V., WILLIAMSON B.-S. 2004 - Microwear and residue analysis in perspective : the contribution of ethnoarchaeological evidence. Journal of Archaeological Science. 31, p. 1287-1299.

ROTTLÄNDER R. 1975 - The formation of patina on flint. Archaeometry, 17, p. 106-110.

ROUSSEL M. 2011 - Normes et variations de la production lithique durant le Châtelperronien. La séquence de la Grande-Roche-de-la-Plématrie à Quincay (Vienne). Thèse de l'université de Paris Ouest Nanterrela-Défense, $554 \mathrm{p}$.

SCANDIUZZI R. 2008 - Les Tambourets, un gisement châtelperronien de plein air au seuil des Petites Pyrénées. Étude de l'industrie lithique. Fouilles H.M. Bricker (1973-1975-1980, Couladère, Haute-Garonne). Mémoire de Master II de l'université Toulouse II Le Mirail, 131p.

SEMENOV S.-A. 1964 - Prehistoric technology ; an experimental study of the oldest tools and artefacts from traces of manufacture and wear. Cory, Adams et Mackay, London. $211 \mathrm{p}$.

SERONIE-VIVIEN M., SERONIE-VIVIEN M.-R. 1987 - Les silex du Mésozoïque nord-aquitain. Approche géologique de l'étude des silex pour servir à la recherche préhistorique. Supplément au Bulletin de la Société Linéenne de Bordeaux XV, 135 p.

SHCHELINSKIJ V. E. 1983 cité par : PLISSON H. 1988 - Technologie et tracéologie des outils lithiques moustériens en Union Soviétique : les travaux de V. E. Shchelinskij. In : Otte M. (Ed.). L'Homme de Néandertal. Actes du Colloque International de Liège (4-7 décembre 1986). ERAUL, 31/4 : La Technique, p. 121-168.

SHOTT M.-J., WEEDMAN K.-J. 2006 - Measuring reduction in stone tools : an ethnoarchaeological study of Gamo hidescrapers from Ethiopia. Journal of Archaeological Science. XX, p. 1-20.

SIGAUT F. 1991 - Un couteau ne sert pas à couper, mais en coupant. Structure, fonctionnement et fonction dans l'analyse des objets. In: 25 ans d'Etudes Technologiques en Préhistoire : bilan et perspectives. Actes des XIe Rencontres Internationales d'Archéologie et d'Histoire d'Antibes, Juanles-Pins (18-20 octobre 1990). APDCA, Sophia Antipolis, p. 21-34. 
SONNEVILLE-BORDES D. 1960 - Le Paléolithique supérieur en Périgord. Imprimerie Delmas,

Bordeaux,

2 volumes, $558 \mathrm{p}$.

SONNEVILLE-BORDES D. 2002 - Les industries du Roc- de-Combe (Lot) : Périgordien et Aurignacien. Préhistoire du Sud-Ouest, 9, (2), p. 121-161.

SOULIER M.C. 2013 - Entre alimentaire et technique : l'exploitation animale aux débuts du Paléolithique supérieur. Stratégies de subsistance et chaînes opératoires de traitement du gibier à Isturitz, la Quina aval, Roc de Combe et les Abeilles. Thèse de Doctorat de l'Université de Toulouse 2 Le Mirail, 196 p.

TRINGHAM R., COOPER G., ODELL G., VOYTEK B., WITHMAN A. 1974 - Experimentation in the Formation of Edge Damage. A New Approach to Lithic Analysis. Journal of Field Archaeology,1, p. 171-196.

TURNER L. M. 1979 - Inuit et Nenenot de l'Ungava. Ed. Desclez, Westmount.

TURQ A. 1992 - Le Paléolithique inférieur et moyen entre les vallées de la Dordogne et du Lot. Thèse de doctorat de l'université de Bordeaux I, 782 p.

VALLIN L., CASPAR J.P., GUILLOMET G., MASSON B., OZOUF J.C. 2013 - Altérations des artefacts préhistoriques en silex par les processus périglaciaires : présentation des expériences conduites au centre de Géomorphologie du CNRS de Caen. Quaternaire, 24, (3), p.259-266.

VANDERMEERSCH B. 1984 - À propos de la découverte du squelette Néandertalien de SaintCésaire. Bulletins et Mémoires de la Société d'Anthropologie de Paris, 14 (1-3), p. 191-196.

WEEDMAN K. 2002 - An ethnoarchaeology study of stone- tool variability among the Gamo Hideworkers of Southern Ethiopia. In : F. Audoin-Rouzeau et S. Beyries (Ed.), Le travail du cuir de la Préhistoire à nos jours. Actes des XXe rencontres d'Archéologie et d'histoire d'Antibes, 2001, Antibes, APDCA, p. 131-141.

WIEDERHOLD J.E. 2004 - Toward the standardization of use-wear studies : constructing an analogue to prehistoric hide work. Thèse de doctorat de l'université $\mathrm{A} \& \mathrm{M}$ du Texas, $241 \mathrm{p}$.

ZILHÃO J., D’ERRICO F. 2000 - La nouvelle « bataille aurignacienne ». Une révision critique de la chronologie du Châtelperronien et de l'Aurignacien. L'Anthropologie, 104, p. 17-50.

ZILHÃO J., D’ERRICO F., BORDES J.-G., LENOBLE A., TEXIER J.-P., RIGAUD J.-P. 2006 - Analysis of Aurignacian interstratification at the Chatelperronian-type and implications for the behavioral modernity of Neandertals. PNAS, 103, (33), p. 12643-12648.

\section{ANNEXES}

Expérimentations du travail des peaux et traces associées. Légende $: \mathrm{ZA}=$ zone active ; Exp. $=$ expérimentateur $;$ att. $=$ attaque $;$ dep. $=$ dépouille $;$ Fréq. raviv. $=$ fréquence $d u$ ravivage $;$ tranch. $=$ tranchant $;$ retouch. $=$ retouché $;$ Châtel. $=$ Châtelperron . 


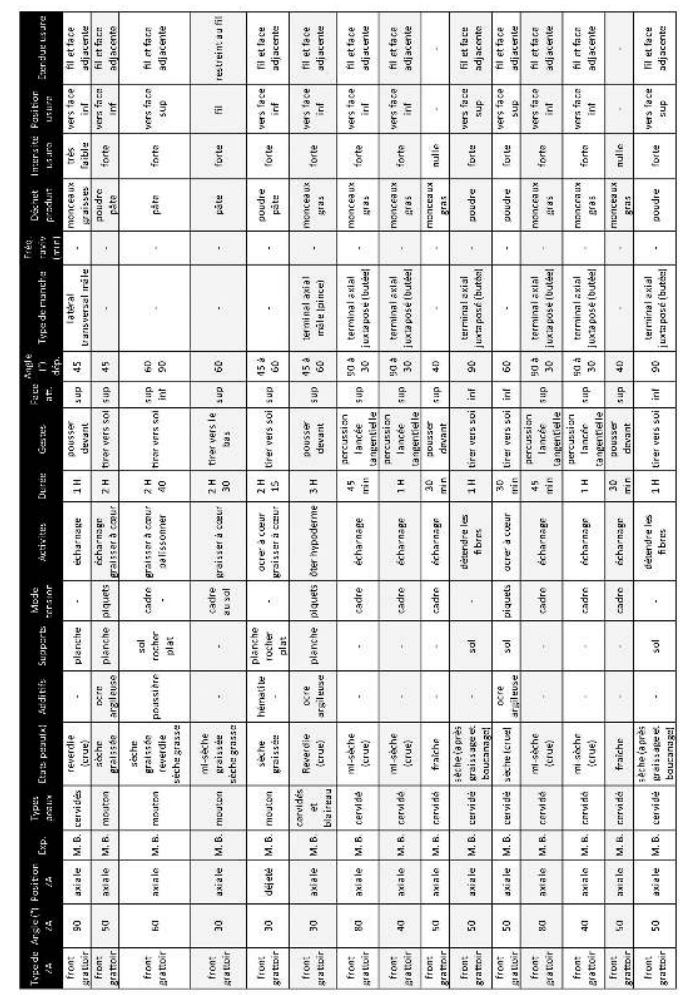

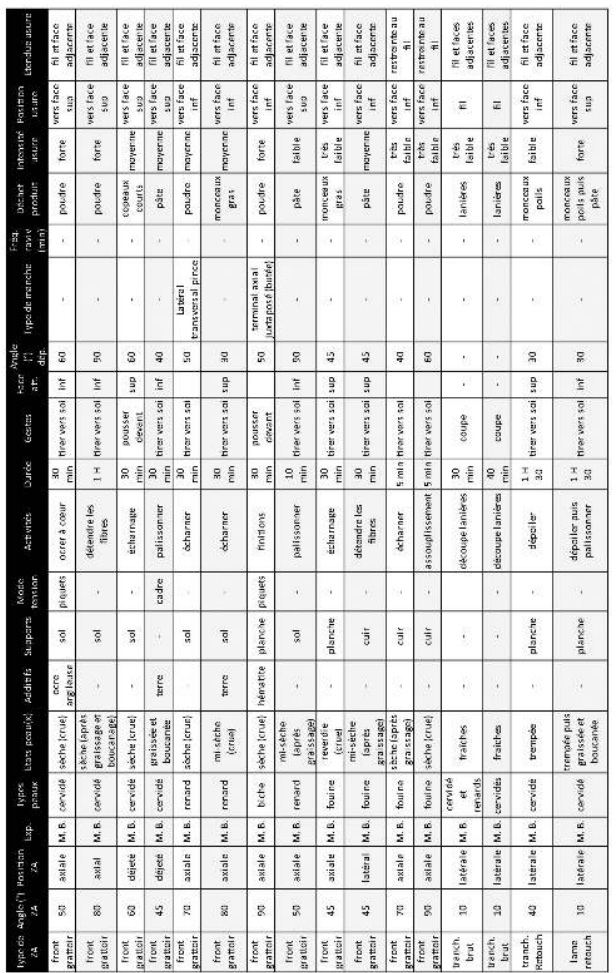



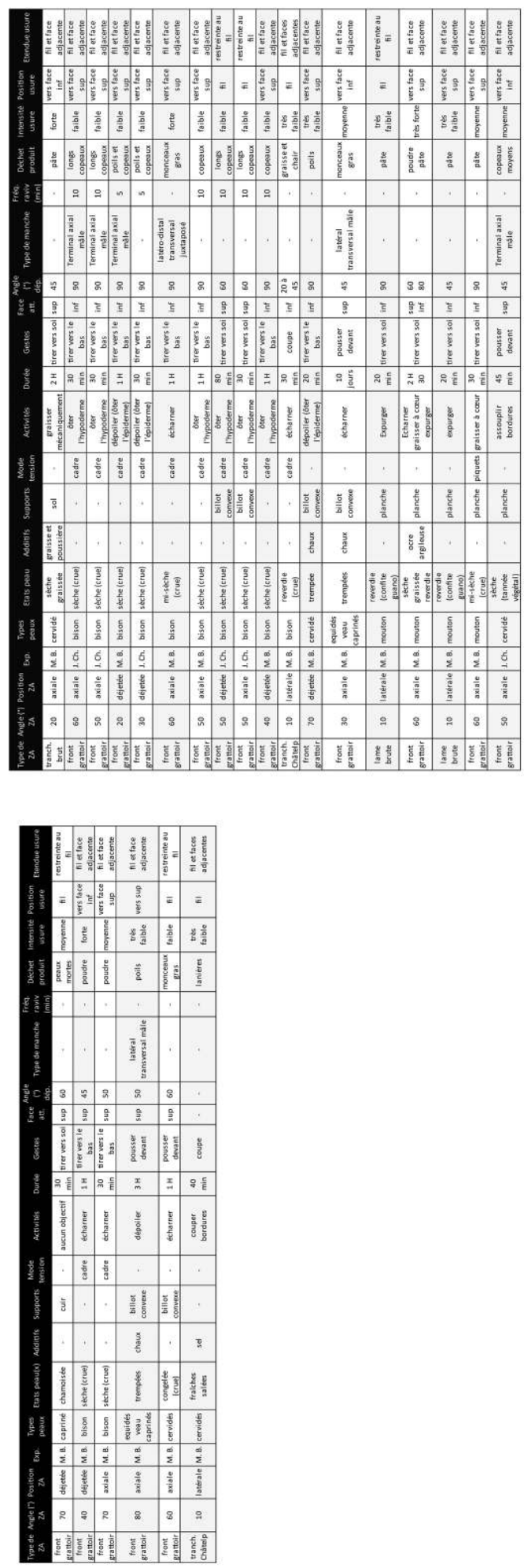

\section{RÉSUMÉS}

Après l'objet emblématique qu'est la pointe de Châtelperron, le grattoir est numériquement parlant l'outil le plus important au sein des assemblages lithiques châtelperroniens. Il n'a 
pourtant été que très peu étudié. L'étude techno-économique, spatiale et fonctionnelle des trente-trois grattoirs provenant du gisement de Canaule II (Creysse, Dordogne) représente donc une occasion d'interroger le statut de ces outils au sein du fonctionnement de ce technocomplexe. À la fois atelier de taille et théâtre d'activités domestiques, ce gisement est en effet particulièrement bien conservé, et permet un bon degré de résolution dans la reconstitution de leur manufacture, leur mode de préhension, leur fonctionnement, leur maintenance et leur abandon. Les résultats de cette étude sont les suivants : 1) Il n'y a pas de production spécifique de supports de grattoirs : ceux-ci sont choisis parmi des grands éclats parfois allongés issus des phases de mise en forme ou d'entretien des nucléus laminaires ; 2) Il existe une variabilité tant en ce qui concerne la morphologie des supports que l'aspect de leur retouche ; 3) Une seule activité est décelable : le raclage de peau sèche entrecoupé de ravivages du tranchant dès l'apparition du moindre émoussement. En nuançant notre interprétation sur une base ethnographique couplée à des expérimentations aux côtés d'un artisan tanneur traditionnel, nous avançons la possibilité qu'il s'agisse ici d'une opération d'amincissement de peaux. Une fois rappelé que cela correspond à une étape opératoire très différente du simple écharnage (à la fois dans leur moment d'intervention, leur principe, ainsi que dans le champ des objectifs possibles), nous concluons $a$ minima que les châtelperroniens de Canaule II possédaient un savoir-faire exigeant en termes de procédé technique, symptomatique d'un véritable artisanat du cuir.

After the Chatelperron knive/point, emblematic object, the endscraper is, numerically speaking, of prime importance within the Chatelperronian lithic industry. However, it remains understudied. The techno-economical, spatial and functional study of the thirty-three endscrapers from Canaule II (Creysse, Dordogne) thus represents an opportunity of questioning the status of these tools within the Chatelperronian technical system. Both flint-knapping workshop and theatre of domestic activities, this site has indeed been well-preserved, and enables a great promise as to the reconstitution of their manufacturing sequence, handling, use, maintenance and abandonment. The results of this study are the following: 1) There is no specific production of endscraper blanks: these are chosen from among the large - sometimes elongated - flakes resulting from the shaping-out or rejuvenation phases of the laminar nucleus; 2) There is a variability as to, as much the morphology of the blanks, as to the aspect of their retouch; 3) One unique use is apparent: the scraping of dried skins, punctuated with the re-sharpening of the working edge as soon as the slightest wear appears. Nuancing our interpretation ethnographically, added to experiments alongside a tanner craftsman, we are putting forward the hypothesis that, here, this is a thinning procedure of skins. Bearing in mind that this corresponds to a very different stage of procedure from that of simple fleshing (both at the time and principle of intervention, as in the field of possible aims), we can conclude a minima that the Chatelperronians of Canaule II possessed an exacting know-how as to technical process, symptomatic of an authentic craftsmanship of leather.

\section{INDEX}

Keywords : endscraper, hide-working, Chatelperronian, techno-morpho-functional analysis, experiments

Mots-clés : grattoir, peausserie, Châtelperronien, approche techno-morpho-fonctionnelle, expérimentations 


\section{AUTEURS}

\section{MICKAËL BAILLET}

UMR 5199 PACEA, Université de Bordeaux, Bât. B8, allée Geoffroy Saint Hilaire, FR-33615 Pessac ; Universidad de Cantabria, Dept. Ciencias históricas, av. de los Castros, ES-39005 Santander michael.baillet@u-bordeaux.fr

\section{FRANÇOIS BACHELLERIE}

UMR 5199 PACEA, Université de Bordeaux, Bât. B8, allée Geoffroy Saint Hilaire, FR-33615 Pessac bachellerie.francois@gmail.com

\section{JEAN-GUILLAUME BORDES}

UMR 5199 PACEA, Université de Bordeaux, Bât. B8, allée Geoffroy Saint Hilaire, FR-33615 Pessac jg.bordes@pacea.u-bordeaux.fr 